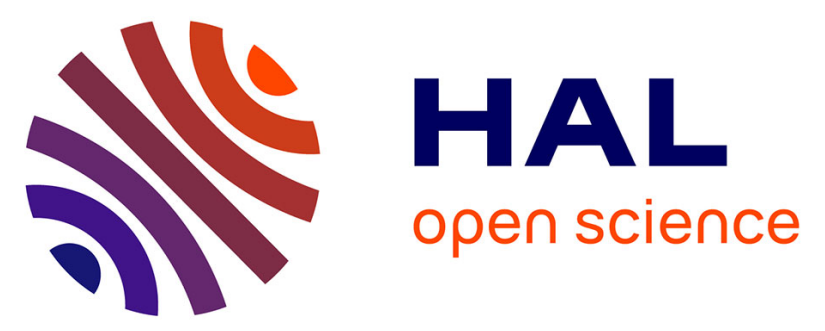

\title{
Historical seismicity of the Mont Dore volcanic province (Auvergne, France) unraveled by a regional lacustrine investigation: New insights about lake sensitivity to earthquakes
}

Léo Chassiot, Emmanuel Chapron, Christian Di Giovanni, Patrick Lajeunesse, K. Tachikawa, Marta Garcia, Edouard Bard

\section{To cite this version:}

Léo Chassiot, Emmanuel Chapron, Christian Di Giovanni, Patrick Lajeunesse, K. Tachikawa, et al.. Historical seismicity of the Mont Dore volcanic province (Auvergne, France) unraveled by a regional lacustrine investigation: New insights about lake sensitivity to earthquakes. Sedimentary Geology, 2016, 339, pp.134 - 150. 10.1016/j.sedgeo.2016.04.007 . hal-01447056

\section{HAL Id: hal-01447056 \\ https://hal-univ-tlse2.archives-ouvertes.fr/hal-01447056}

Submitted on 26 Jan 2017

HAL is a multi-disciplinary open access archive for the deposit and dissemination of scientific research documents, whether they are published or not. The documents may come from teaching and research institutions in France or abroad, or from public or private research centers.
L'archive ouverte pluridisciplinaire HAL, est destinée au dépôt et à la diffusion de documents scientifiques de niveau recherche, publiés ou non, émanant des établissements d'enseignement et de recherche français ou étrangers, des laboratoires publics ou privés. 


\title{
Historical seismicity of the Mont Dore volcanic province (Auvergne, France) unraveled by a regional lacustrine investigation: New insights about lake sensitivity to earthquakes
}

\author{
Léo Chassiot $^{\text {a,* }}$, Emmanuel Chapron ${ }^{\text {a,b }}$, Christian Di Giovanni ${ }^{\text {a }}$, Patrick Lajeunesse ${ }^{c}$, Kazuyo Tachikawa ${ }^{\text {, }}$, \\ Marta Garcia ${ }^{\mathrm{d}}$, Edouard Bard ${ }^{\mathrm{d}}$ \\ a Institut des Sciences de la Terre d'Orléans (ISTO), UMR 7327, CNRS, Université d'Orléans, BRGM, 1 A rue de la Férollerie, 45071 Orléans Cedex 2, France \\ ${ }^{\mathrm{b}}$ Géographie de l'Environnement (GEODE), UMR 5602, CNRS, Université Toulouse 2 Jean Jaurès, Allée A. Machado, 31058 Toulouse Cedex, France \\ ' Centre d'Etudes Nordiques (CEN), Département de Géographie, Université Laval, Pavillon Abitibi-Price, 2405, rue de la Terrasse, Québec G1V 0A6, Canada \\ d Centre Européen de Recherche et d'Enseignement en Géosciences (CEREGE), UM 34, CNRS, Université Aix-Marseille, IRD, Collège de France, 13545 Aix-en-Provence, France
}

\section{A R T I C L E I N F O}

\section{Article history:}

Received 5 February 2016

Received in revised form 11 April 2016

Accepted 12 April 2016

Available online 20 April 2016

Editor: Dr. J. Knight

\section{Keywords:}

Volcanic lakes

Mass-wasting deposits

Earthquakes

Lake sensitivity

Paleoseismology

French Massif Central

\begin{abstract}
A B S T R A C T
Lake sediments are relevant natural seismographs over long time scale. However, because tectonic events are not systematically recorded in lake sediments, one forthcoming challenge for paleoseismology is to better assess lake sensitivity to earthquakes. To this end, a limnogeological investigation, including hydroacoustic mapping techniques, core sampling and multi-proxy sediment analyses, has been conducted within four small volcanic lakes located in the Mont Dore province (Auvergne, France), an area with a moderate seismo-tectonic activity. Results show the existence of several gravity reworking processes in the lakes over the last millennium. Around AD 1300, the occurrence of synchronous events in lakes Pavin, Chauvet, Montcineyre and Guéry ( $100 \mathrm{~km}^{2}$ area) highlights an undocumented earthquake as a common trigger for slope failures in disconnected basins. At regional scale, the record of this tectonic event may have been favored by human-induced increase in sediment load (Chauvet and Montcineyre) and/or after an abrupt lake-level drop (Pavin) affecting the sediment stability. In addition, synchronous turbidites and mass-wasting deposits (MWD) recorded in lakes Pavin and Guéry provide evidence for a seismic activity during the XIX ${ }^{\text {th }}$ century. Potential triggers are historical earthquakes that occurred either in the Mont Dore area or in the southern part of the Limagne fault at this time. Despite moderate seismic activity in this intraplate volcanic domain, these results highlight the role of tectonics as a major trigger in the sedimentary processes dominating these lacustrine infills. Within the diversity of studied sites, it appears that lake sensitivity to earthquakes was not constant over time. This sensitivity can be expressed as a combination of external factors, namely earthquake magnitude and lake-epicenter distance and internal factors such as lake morphology, nature of sediment, lake-level fluctuations and human-induced changes in catchment sedimentary load.
\end{abstract}

(c) 2016 Elsevier B.V. All rights reserved.

\section{Introduction}

Metropolitan France is a country of low seismotectonic activity (Baize et al., 2013). The seismotectonic zonation established from both geological background and evidence of Neogene tectonic activity leads to a regional-scale seismic hazard assessment, which is highly variable within the country (Terrier et al., 2000; Baize et al., 2013). According to SISFRANCE and AHEAD databases (Lambert et al., 1997; Baumont and Scotti, 2011; Stucchi et al., 2013), compressing stress zones like the Alps and the Pyrenees host active faults favoring the generation of recurrent and in some cases large earthquakes (magnitude $\geq 6$ ). Major tectonic features located near Hercynian chains are also responsible

\footnotetext{
* Corresponding author.

E-mail address: leo.chassiot@hotmail.fr (L. Chassiot).
}

for smaller tectonic events (magnitude $\leq 6$ ), as in the Armorican Massif or the French Massif Central (Lambert et al., 1997). In both settings, the instrumental records span the last century, which remains problematic to assess the seismic hazard for events of long return periods. Hence, extending earthquake records beyond this time window is a key issue for understanding regional seismicity and hazard risk.

Over the last decades, lake sediments have been analyzed for their relevance to record seismic events and have been successfully used as natural seismographs for long-term record of earthquake-induced sedimentary disturbances (Strasser et al., 2013). Today, many studies use various forms of instantaneously formed sedimentary deposits or structures for qualitative and quantitative earthquake reconstructions in lacustrine systems during the Holocene, as long as the seismic origin of these deposits is clear. Most of these studies are concentrated in tectonically active regions such as the Alps (Beck et al., 1996; Schnellmann et al., 2002; Monecke et al., 2004; Nomade et al., 2005; Strasser et al., 
2006, 2013; Wilhelm et al., 2015; Chapron et al., 2016), the Anatolian fault (Schwab et al., 2009; Avşar et al., 2014, 2015) and around the Pacific where recurrent and large earthquakes have been recently experienced such as in Chile (Chapron et al., 2006; Bertrand et al., 2008; Moernaut et al., 2007, 2014), US western coast (Karlin et al., 2004; Maloney et al., 2013; Morey et al., 2013; Smith et al., 2013), Japan (Inouchi et al., 1996) or New Zealand (Howarth et al., 2014; Gomez et al., 2015). Moreover, recent limnogeological investigations in glacial lakes of the mid-continental North America underline the ability of sediment to archive earthquakes throughout the Holocene, despite the low to moderate magnitude of earthquakes that occurred in this intraplate domain (St-Onge et al., 2004; Doughty et al., 2014; Lajeunesse et al., in press; Locat et al., 2016). However, because earthquakes do not systematically trigger mass-movement deposits in lake basins, one forthcoming challenge for paleoseismology is the characterization of lake sensitivity to earthquakes, which can vary from one lake to another (Wilhelm et al., 2015).

In order to contribute to the growing interest of earthquake records in lacustrine environments, the present study focuses on the volcanic province of the Mont Dore area (French Massif Central) where a limited but existent tectonic activity has been reported for the last halfmillennium (Lambert et al., 1997; Stucchi et al., 2013). This region hosts various types of small volcanogenic lakes which are, with rare exceptions, barely known in limnogeological terms. Supporting pioneer works published by Chapron et al. (2012), the present study provides an up-to-date dataset of high-resolution seismic profiles coupled to radiocarbon-dated sediment cores from four nearby lakes $\left(100 \mathrm{~km}^{2}\right.$ area), including maar Lake Pavin (Schettler et al., 2007; Chapron et al., 2010, 2012; Chassiot et al., 2016), maar Lake Chauvet (Juvigné, 1992), volcanic-dam Lake Montcineyre (Chapron et al., 2012) and the poorly documented glacial Lake Guéry (Fig. 1). This regional dataset also improve the scope of earthquakes that triggered turbidites recently described in Lake Pavin sedimentary archives (Chassiot et al., 2016).

\section{Regional setting}

\subsection{Geological background}

The French Massif Central hosts a succession of volcanic edifices along a North-South transect. Among them, the Puy-de-Dôme culminates at $1465 \mathrm{~m}$ a.s.l. above the Chaîne-des-Puys, a volcanic province separated from the Limagne graben by a normal fault (Boivin et al., 2009). The Limagne fault is a major tectonic structure of an Oligocene rifting episode (Merle et al., 1998) (Fig. 1B). The Sancy stratovolcano

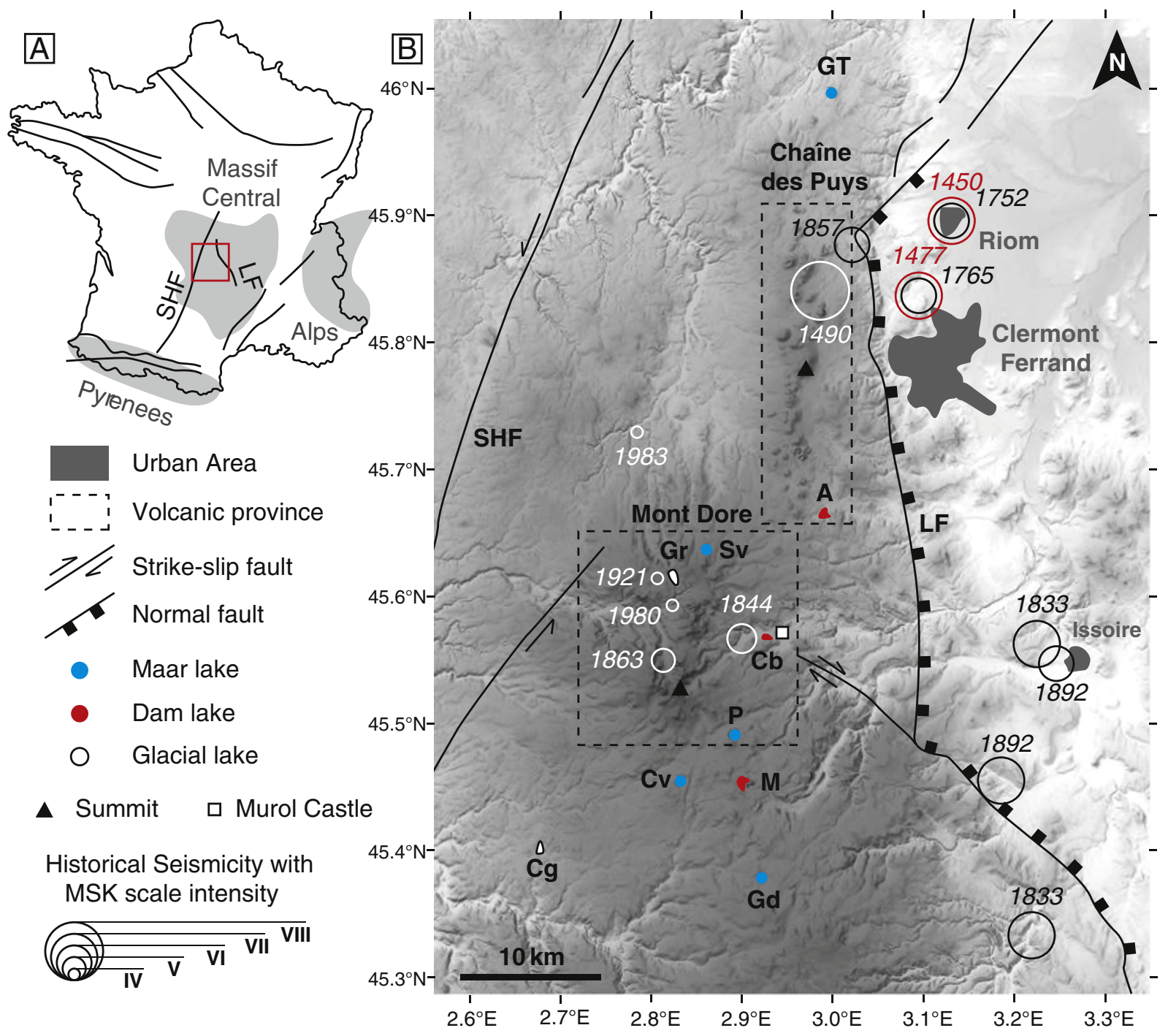

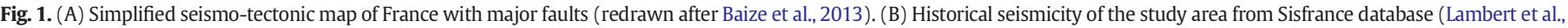

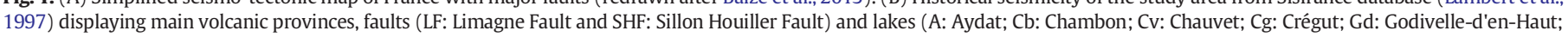
GT: Gour de Tazenat; Gr: Guéry and P: Pavin). 
(1886 $\mathrm{m}$ a.s.l.) was formed during the Pleistocene and constitutes the youngest stratovolcano of the Mont-Dore volcanic province (Nomade et al., 2012, 2014). At larger scale, the regional tectonic setting is constrained by the Sillon Houiller fault on the west side, along with two strike-slip faults converging to the Mont Dore massif (Fig. 1B). In this region, both volcanic activity and glacial erosion shaped the landscape to form several lakes with various morphologies (Rioual, 2002) (Table 1). This includes crater or maar lakes with a high depth-area ratio, resulting from phreato-magmatic explosion, but also narrow volcanic-dam lakes and shallow glacial lakes (Fig. 1B).

\subsection{Historical seismicity}

By comparison with active mountain ranges such as the Alps or the Pyrenees, the Auvergne region is characterized by a low seismic activity (Lambert et al., 1997; Baize et al., 2013). According to SISFRANCE and AHEAD databases (Baumont and Scotti, 2011; Stucchi et al., 2013), several seismic events with epicentral MSK scale intensities ranging from IV to VIII have taken place in the last 500 years (Fig. 1B). The best examples are the large historical earthquakes occurring in $\mathrm{AD}$ 1477 and AD 1490 at the boundary between the Chaîne-des-Puys and Limagne fault, attested by severe damages in the cities of Riom and Clermont-Ferrand (Lambert et al., 1997). At the epicenter, the moment magnitude (Mw) of these events was estimated at $6.1 \pm 0.3$ with a MSK intensity (Io) of VIII, but was felt in a radius of $20 \mathrm{~km}$ with an Io of VII. In the vicinity, three other medium earthquakes also occurred in $\mathrm{AD} 1752$ ( $\mathrm{Io}=\mathrm{V} 1 / 2$ and $\mathrm{Mw}=4.1 \pm 0.3$ ), $\mathrm{AD} 1765$ ( $\mathrm{Io}=\mathrm{V} 1 \frac{1}{2}$ and $\mathrm{Mw}=4.1 \pm 0.3$ ) and $\mathrm{AD} 1857$ ( $\mathrm{Io}=\mathrm{V}^{1} \frac{1}{2}$ and $\mathrm{Mw}=4.9 \pm 0.3$ ). In addition, south along the Limagne fault, seismic activity has been reported near the city of Issoire, where historical earthquakes occurred in $\mathrm{AD} 1833$ ( $\mathrm{Io}=\mathrm{VI}$ and $\mathrm{Mw}=5 \pm 0.3$ ) and $\mathrm{AD} 1892$ ( $\mathrm{Io}=\mathrm{VI} 1 \frac{1}{2}$ and $\mathrm{Mw}=5.5 \pm 0.3)$. At the heart of the Mont Dore volcanic area, limited but recurrent earthquakes have also been noted during the XIX ${ }^{\text {th }}$ century, with small seismic shakings in AD 1844 (Chambon-sur-lac: Io $=\mathrm{V} 1 \frac{1}{2}$ and unknown Mw) and $\mathrm{AD} 1863$ (Mont Dore: Io $=\mathrm{V}$ and $\mathrm{Mw}=3.4 \pm 0.6)$. Finally, over the last century, many other small earthquakes (Io $=$ IV) have also been recorded in the region, but we limit the dataset to those occurring in Mont Dore area, according to the SISFRANCE database (Lambert et al., 1997; Baumont and Scotti, 2011). Overall, the distribution of earthquake epicenters highlights the connection between local seismic activity and regional tectonics, with a concentration of seismic events along the Limagne fault and near the strike-slip faults converging beneath the Mont Dore massif (Fig. 1B). This neotectonic evidence stresses the role of the rifting in modern seismic activity, even if this region is nowadays considered as a barely active system according to the seismo-tectonic zoning scheme defined by Baize et al. (2013). At a regional scale, the lack of knowledge on the seismo-tectonic framework and the fault distribution at local scales remains problematic for detailed investigations within the volcanic provinces in Auvergne.

\section{Materials and methods}

\subsection{Lacustrine morphologies and core sampling}

Lacustrine morphologies and sedimentary infill geometries were deciphered with high-resolution acoustic stratigraphy surveys using a Knudsen subbottom profiler with an acoustic Chirp source at the frequencies of 4 and $12 \mathrm{kHz}$. The morphology of Lake Pavin was in addition investigated using a Reson Seabeat 8101 multibeam echosounder allowing us to generate a high-resolution $(50 \mathrm{~cm} \times 50 \mathrm{~cm})$ bathymetric map (Fig. 3) (Chapron et al., 2010; Chassiot et al., 2016). For the other lakes, a total of $12 \mathrm{~km}$ of seismic lines with a maximal spacing of $200 \mathrm{~m}$ (lakes Chauvet and Montcineyre) and $100 \mathrm{~m}$ (Lake Guéry) were gathered in the SEG-Y format using IHS The Kingdom Suite ${ }^{\mathrm{TM}}$ software. Lake floors were digitalized in two-way travel-time (TWT) as identified on the acoustic data and then exported to ArcGISTM software to build bathymetric maps considering a P-wave velocity of $1500 \mathrm{~m} \mathrm{~s}^{-1}$ and a picking uncertainty of $10 \mathrm{~cm}$ (Fig. 2). According to basin floor morphologies and sedimentary facies identified through acoustic images, sedimentary cores were collected using an UWITEC ${ }^{\mathrm{TM}}$ gravity corer in Lake Montcineyre (core MO10-H at $9 \mathrm{~m}$ water depth) and a Bobcore gravity corer in Lake Guéry (core G11-B at $14.5 \mathrm{~m}$ water depth and core G11-C at $13 \mathrm{~m}$ water depth) and Lake Chauvet (core CHA13-7B at $63 \mathrm{~m}$ water depth). In Lake Pavin deep basin (92 $\mathrm{m}$ ), a piston corer settled on a UWITEC ${ }^{\mathrm{TM}}$ platform was used to drill two holes allowing the recovery of the entire sedimentary sequence (core PAV12). All cores were packed and stored in a cold room $\left(4^{\circ} \mathrm{C}\right)$ at the ISTO laboratory before sampling and analyses.

\subsection{Multi-proxy analyses}

Cores were split in two halves and carefully observed. Visual analyses, combined to a multi-proxy approach, allow us to distinguish background sedimentation from sedimentary events. This multi-proxy approach includes spectrophotometric measures every half centimeter using a Minolta ${ }^{\mathrm{TM}} \mathrm{CM}-700 \mathrm{~d}$. A spectral mapping of each core has been computed using First Derivatives reflectance Spectra (FDS) of the visible light spectrum (Debret et al., 2011), as represented by multicolored images ranging from $\mathrm{d} 405$

Table 1

Morphological characteristics of lakes presented in Fig. 1 updated from Rioual (2002).

\begin{tabular}{|c|c|c|c|c|c|c|c|}
\hline Lake & Type & $\begin{array}{l}\text { Altitude } \\
\text { (m a.s.l.) }\end{array}$ & $\begin{array}{l}\text { Max depth } \\
(\mathrm{m})\end{array}$ & $\begin{array}{l}\text { Area } \\
\left(\mathrm{km}^{2}\right)\end{array}$ & $\begin{array}{l}\text { Catchment area } \\
\left(\mathrm{km}^{2}\right)\end{array}$ & Age & Selected references \\
\hline Pavin & Maar & 1197 & 92 & 0.44 & 0.36 & 7000 cal. BP & $\begin{array}{l}\text { Schettler et al., } 2007 \\
\text { Chapron et al., 2010, } 2012 \\
\text { Chassiot et al., } 2016\end{array}$ \\
\hline Chauvet & Maar & 1166 & 63 & 0.52 & 1.3 & Late Glacial & $\begin{array}{l}\text { Juvigné, } 1992 \\
\text { Chapron et al., } 2012\end{array}$ \\
\hline Montcineyre & Volcanic dam & 1174 & 20 & 0.39 & 1.5 & 7500 cal. BP & Chapron et al., 2012 \\
\hline Guéry & Glacial & 1246 & 15 & 0.26 & 6.5 & $?$ & - \\
\hline La Crégut & Glacial & 856 & 26 & 0.33 & $1.5\left(86^{\mathrm{a}}\right)$ & $?$ & Chassiot (2015) \\
\hline Aydat & Volcanic dam & 825 & 15 & 0.60 & 3 & 8500 cal. BP & Lavrieux et al., 2013 \\
\hline Chambon II & Landslide dam & 880 & 4 & 0.51 & 36 & $2600 \mathrm{BP} ?$ & $\begin{array}{l}\text { Macaire et al., } 1997 \\
\text { Gay and Macaire, } 1999\end{array}$ \\
\hline Servière & Maar & 1200 & 29 & 0.16 & 0.50 & $?$ & - \\
\hline La Godivelle d'en Haut & Maar & 1239 & 44 & 0.14 & 0.13 & Late Glacial & $\begin{array}{l}\text { Bastin et al., } 1991 \\
\text { Juvigné, } 1992\end{array}$ \\
\hline Gour de Tazenat & Maar & 630 & 66 & 0.33 & 4.18 & $?$ & Juvigné and Stach-Czerniak, 1998 \\
\hline
\end{tabular}

\footnotetext{
a Present-day catchment area according to hydraulic connections with reservoirs and rivers upstream.
} 


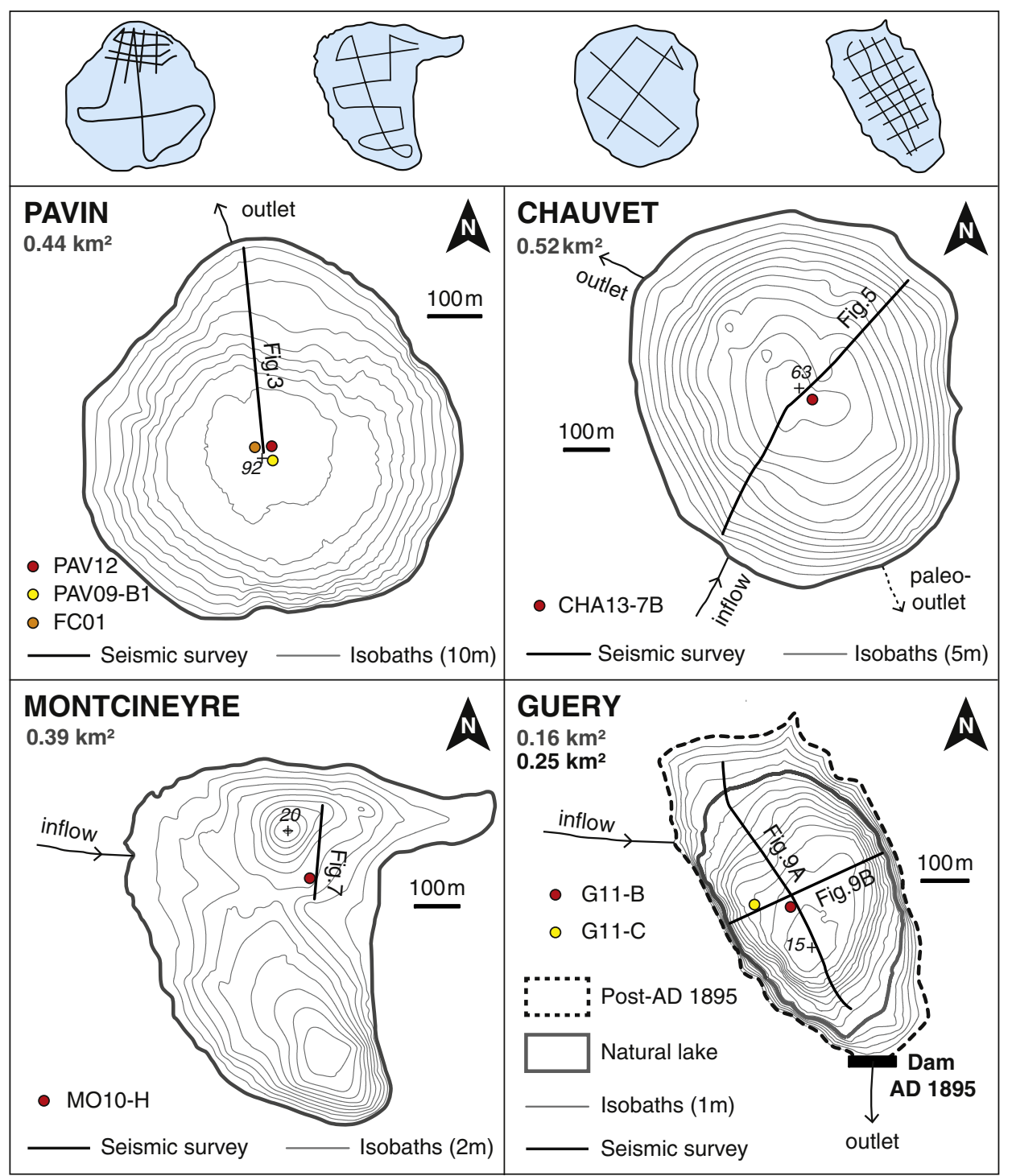

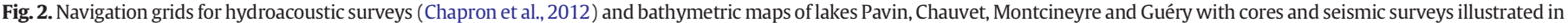
corresponding figures. Crosses indicate the deepest points.

to d695 in corresponding figures. Continuous handheld measures of the magnetic susceptibility (MS) were also performed with the same resolution using a Bartington ${ }^{\mathrm{TM}}$ MS2E Core Logging Sensor (error of instrument less than $2 \%$ ). The organic fraction of the sediment has also been analyzed using Rock-Eval (RE) pyrolysis (Behar et al., 2001) in order to assess the Total Organic Carbone (TOC) content. A quantitative observation of organic palynomorphs has been made under transmitted light (i.e., palynofacies) to determine the origin (terrigenous vs. algal) of organic matter (OM) (Simonneau et al., 2013). For each sedimentary unit described in cores, results are synthetized by blue and brown pie charts in corresponding figures. In addition, for sediments retrieved from Lake Guéry, X-rays radiographies were achieved on u-channels with a $200 \mu \mathrm{m}$ resolution using an ITRAX core scanner (Cox Analytical Systems, Croudace et al., 2006). The applied settings were $45 \mathrm{kV}$ and $40 \mathrm{~mA}$ for a time acquisition of $600 \mathrm{~ms}$ with a $\mathrm{Cr}$ tube. Finally, sedimentary events identified within cores PAV12 and CHA13-7B have been sampled for grain-size analyses using a Malvern ${ }^{\mathrm{TM}}$ Mastersizer 3000 with a sampling interval of $1 \mathrm{~cm}$ (CHA13-7B) and $2 \mathrm{~cm}$ (PAV12). Grain size values were computed in the Excel-running GRADISTAT program (Blott and Pye, 2001) following the Folk and Ward method (Folk and Ward, 1957).

\subsection{Chronology}

Organic debris $(n=7)$ and bulk sediment $(n=3)$ have been sampled within four cores for AMS radiocarbon dating (Table 2). Once the sedimentary events removed, conventional radiocarbon ages were gathered into the CLAM software (Blaauw, 2010) to build age-depth models using the reference calibration curve IntCal13 (Reimer et al., 2013). For the upper unit of core PAV12, the age-depth model used the varve chronology established by Schettler et al. (2007) on a $197 \mathrm{~cm}$-length freeze-core (FC01) covering the last 700 years (i.e., cal. AD 1282-1999). Core-to-core correlation is supported by the large uncertainties obtained from calibrated ages sampled in core PAV12 (Fig. 4, Table 2), as described in Chassiot et al. (2016). In Lake Chauvet, the top-core CHA13-7B does not contain any organic remains. The age-depth model was thus established using three bulk sediments sampled at 16.5, 30 and $51.5 \mathrm{~cm}$, respectively, and one organic debris sampled at $83 \mathrm{~cm}$ depth (Table 2). Palynofacies observations have been used to determine the proportion of terrestrial carbon that may induce a significant error in age modeling using bulk sediments (i.e., the “old carbon" effect, e.g., Grimm et al., 2009; Bertrand et al., 2012). 
Table 2

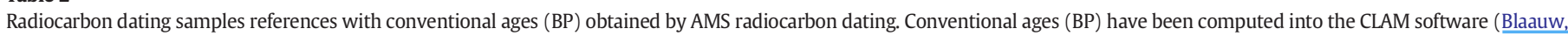

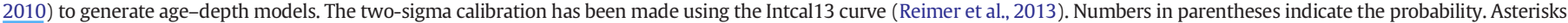
refer to a radiocarbon plateau.

\begin{tabular}{|c|c|c|c|c|c|c|}
\hline Lake & Core & Depth & Laboratory reference & Material & $\begin{array}{l}\text { Conventional age } \\
\text { (BP) }\end{array}$ & $\begin{array}{l}\text { Two sigma calibration } \\
\text { (cal. BP) }\end{array}$ \\
\hline \multirow[t]{2}{*}{ Pavin } & PAV09-B1 & $96.5 \mathrm{~cm}$ & Poz-33126 & Leaf & $150 \pm 30$ & $200 \pm 30(0.33)^{*}$ \\
\hline & PAV12 & $137 \mathrm{~cm}$ & Lyon-10961 & Leaf & $220 \pm 30$ & $285 \pm 20(0.40)^{*}$ \\
\hline \multirow[t]{4}{*}{ Chauvet } & CHA13-7B & $16.5 \mathrm{~cm}$ & Beta-409402 & Gyttja & $680 \pm 30$ & $660 \pm 20(0.64)^{*}$ \\
\hline & & $30 \mathrm{~cm}$ & Beta-409403 & Gyttja & $790 \pm 30$ & $710 \pm 40(1)$ \\
\hline & & $51.5 \mathrm{~cm}$ & Beta-409404 & Gyttja & $1170 \pm 30$ & $1115 \pm 65(0.85)$ \\
\hline & & $83 \mathrm{~cm}$ & Beta-362775 & Leaf & $2360 \pm 30$ & $2400 \pm 70(0.99)$ \\
\hline \multirow[t]{2}{*}{ Montcineyre } & M010-H & $16.5 \mathrm{~cm}$ & UCIAMS-92405 & Leaf & $485 \pm 15$ & $520 \pm 15(1)$ \\
\hline & & $86.5 \mathrm{~cm}$ & UCIAMS-92408 & Leaf & $735 \pm 15$ & $675 \pm 10(1)$ \\
\hline \multirow[t]{2}{*}{ Guéry } & G11-B & $52 \mathrm{~cm}$ & Beta-320655 & Leaf & $110 \pm 30$ & $80 \pm 70(0.69)^{*}$ \\
\hline & & $81 \mathrm{~cm}$ & Beta-320656 & Wood & $390 \pm 30$ & $470 \pm 40(0.73)^{*}$ \\
\hline
\end{tabular}

Age-depth models of cores M010-H and G11-B were performed using organic debris (Table 2). The top-core chronology of core G11-B was also improved with the identification of a major shift in the sedimentary dynamic, likely connected to the dam construction in AD 1895.

\section{Results}

\subsection{Lake Pavin}

Formed ca. 7000 years ago (Juvigné et al., 1996; Chapron et al., 2010), Lake Pavin presently dwells in a former maar resulting from a phreato-magmatic explosion (Fig. 2, Table 1). Consequently, its shape is almost circular $\left(0.44 \mathrm{~km}^{2}\right)$ with a diameter of $700 \mathrm{~m}$ and a maximum water depth of $92 \mathrm{~m}$ in the central basin. Inner slopes of the topographic catchment area $\left(0.36 \mathrm{~km}^{2}\right)$ are very steep and enhance the runoff of rainwater along with multiple streams located around the lake. Previous work described the presence of (1) annually deposited diatomaceous sediment (i.e., diatomite) (Schettler et al., 2007; Chapron et al., 2010, 2012); (2) sedimentary events recording past extreme environmental changes, including a crater rim break with a lake outburst and the record of a mass-wasting deposit in the sedimentary record in AD 600; and (3) a large slope failure around AD 1300 and recurrent turbidites in the XIX ${ }^{\text {th }}$ century (Chassiot et al., 2016) (Fig. 3). As previously described in Chapron et al. $(2010,2012)$, the gas-rich sediment in the lake bottom precludes the penetration of acoustic waves (with sources of either 3.5 or $12 \mathrm{kHz}$ ) (Fig. 3). Nevertheless, a recent coring campaign collected a composite sequence (PAV12) that covers the sedimentary evolution since the formation of the lake (Fig. 4A). From top to bottom, core PAV12 displays four main lithozones with (1) an upper diatomite unit (0-207 cm depth); (2) a package of various massive units (i.e., a light green unit, tilted lamina, a dark green unit, a dark brown unit and a patchwork of disrupted diatomite); (3) a lower diatomite unit; and (4) a basal grey unit made of lamina interrupted by massive units displaying coarse bases and fining-upward sequences (Chassiot et al., 2016). The transition from the upper diatomite to the light green unit is highlighted by major changes in the FDS spectral map suggesting drastic changes in sediment composition. Through the upper $2 \mathrm{~m}$-length diatomite unit, the TOC content varies from 4 to $9 \%$.The organic petrography indicates an algal-dominated organic sedimentation (Fig. 4A). In the $70 \mathrm{~cm}$ thick light green unit, grain-size analyses indicate a silty to sandy sediment (Fig. 4A). Textural parameters display a low mean grain-size value $(21.19 \pm 3.96 \mu \mathrm{m})$, very poorly sorted $(4.40 \pm 0.44)$ with highly variable values in skewness $(0.08 \pm 0.08)$ and kurtosis $(0.96 \pm 0.05)$

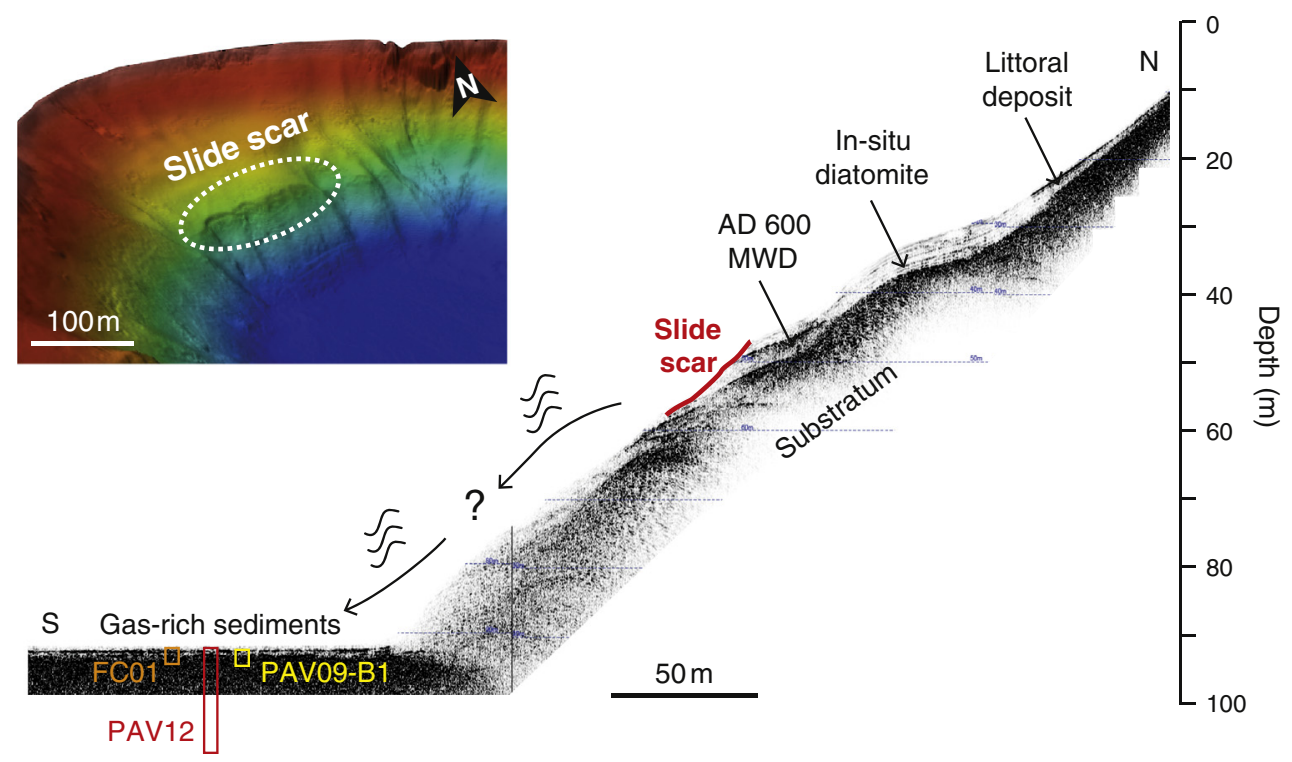

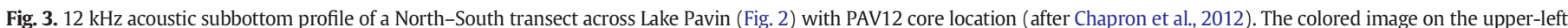

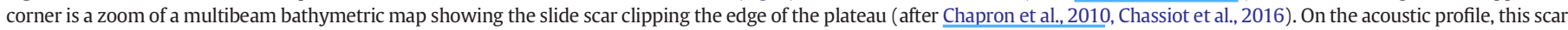

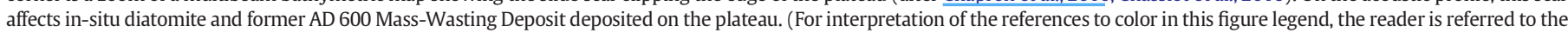
web version of this article.) 

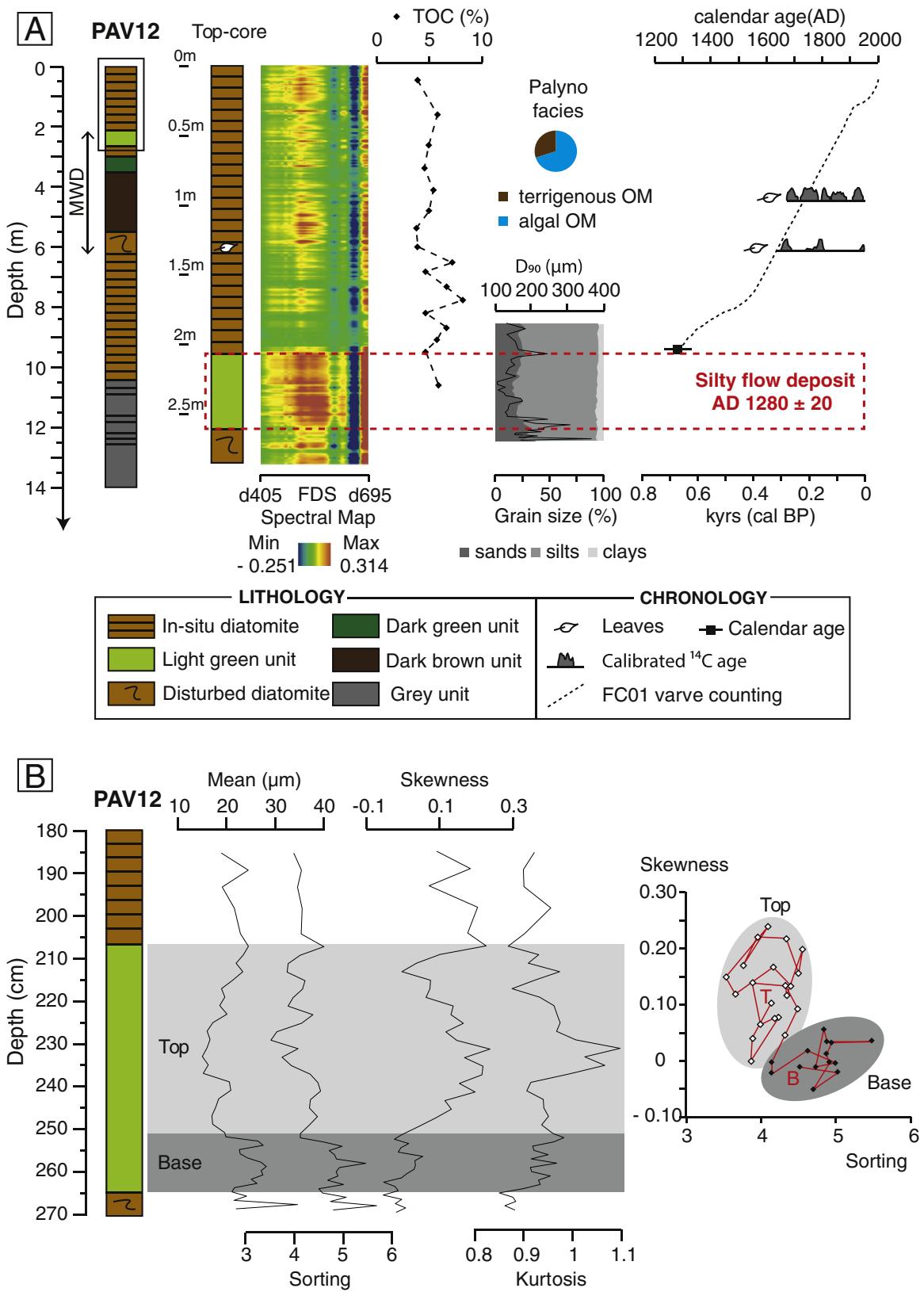

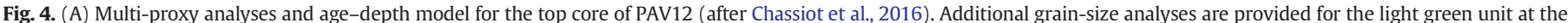

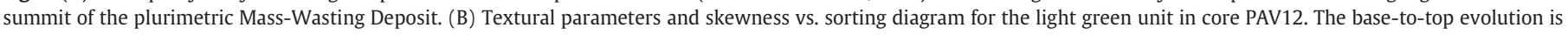
indicated by a red line. (For interpretation of the references to color in this figure legend, the reader is referred to the web version of this article.)

parameters (Fig. 4B). The skewness vs. sorting plot clearly separates the top and the base of the light green unit identified at the top of the MWD in core PAV12 (Fig. 4B). Across these units, the bottom (B) to top (T) path shows a decrease in sorting values along with an increase in skewness values. However, one can notice the base-to-top evolution in the skewness vs. sorting plot does not follow a straight path (Fig. 4B).

\subsection{Lake Chauvet}

Twin of Lake Pavin, Lake Chauvet $\left(0.52 \mathrm{~km}^{2}\right)$ is a 63 m deep maar lake located at the southern boundary of the Mont Dore province (Fig. 2, Table 1). Juvigné (1992) demonstrated its phreato-magmatic origin, despite the absence of a crater rim. According to this author, this can be explained by the overlying ice cap that disturbed the ejection of volcanic materials when the explosion occurred during the late Pleistocene. Indeed, the presence of moraines at its southern side indicates a former lake outlet downstream the glacier advance from the Puy-de-Sancy (Juvigné, 1992) (Fig. 2). This hypothesis has then been confirmed by acoustic profiles $(12 \mathrm{kHz})$ illustrating subaquatic moraines separating several sedimentary basins across the lake (Chapron et al., 2012) (Fig. 5). The acoustic image across Lake Chauvet illustrates a global bowl-shaped morphology, typical of a maar lake, with steep slopes from the littoral to the lake bottom (Fig. 5). The deepest part of the lake shows a succession of small sedimentary basins separated by a moraine ridge (Chapron et al., 2012). On the southwestern side, in the continuity of the river inflow, the acoustic facies displays chaotic packages of sediments. Within the deep basins, the sedimentary infill has developed a stratified acoustic facies with several high amplitude and continuous reflections. The entire sedimentary sequence did not exceed $6 \mathrm{~m}$ thick at core site (Fig. 6).

In the deep basin, one coring campaign allowed retrieving a $95 \mathrm{~cm}$ long gravity core CHA13-7B (Fig. 6). From top to bottom, core CHA13- 


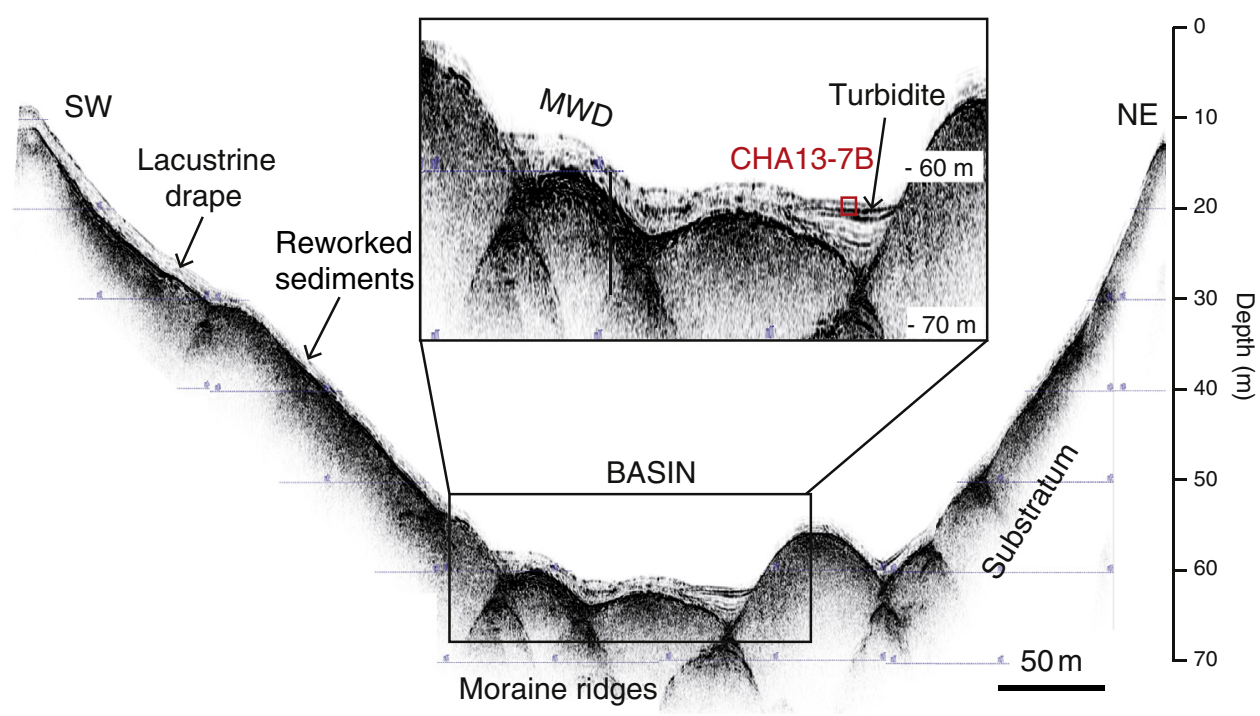

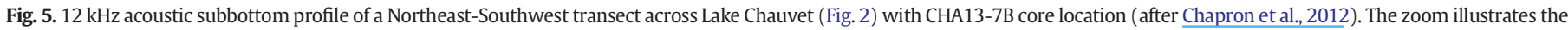
basin fill geometries between moraines ridges with reworked sediment (Mass-Wasting Deposit) at the downslope and laminated facies in the distal part of the sub-basin.

7B exhibits a brown unit (U1, $0-16.5 \mathrm{~cm}$ depth), a light brown unit (U2a, 16.5-32.5 cm depth), a greenish homogeneous unit with a sandy base capped by a with lamina ( $T, 32.5-39.5 \mathrm{~cm}$ depth), a second light brown unit (U2b, 39.5-50.5 cm depth) and a laminated dark brown unit (U3, 50.5-95 cm depth). At the top core, units $\mathrm{U} 1$ and U2 are characterized by low to medium MS values and an organic content between 5 and $10 \%$ of TOC. Organic petrography confirms the abundance of algal organic matter throughout these two units. At the bottom of the core, the laminated unit U3 displays a fluctuating but elevated TOC content, mostly over $10 \%$, whose organic fraction is essentially composed of terrigenous supplies. The greenish homogeneous unit is characterized by a normal grading underlined by a peak in both $D_{90}$ parameter and MS values (Fig. 6A). In contrast to units $\mathrm{U} 1$ and $\mathrm{U} 2$, this unit also displays high mean grain-size values (49.48 $\pm 5.62 \mu \mathrm{m})$, very poorly sorted $(3.55 \pm 0.37)$ with highly variable values in skewness $(-0.02 \pm 0.06)$ and kurtosis $(1.01 \pm 0.02)$ parameters (Fig. 6B). Above this unit, the white lamina displays a very high skewness value without increase in clay content. In the skewness/sorting diagram, the base-to-top evolution indicates a decreasing trend in both sorting and skewness values (Fig. 6B).

\subsection{Lake Montcineyre}

Shortly before the Pavin crater explosion, ca. 7500 years ago, the growth of the Montcineyre volcano dammed the valley where a small river was flowing (Juvigné et al., 1996). Nowadays, the resulting Lake Montcineyre $\left(0.39 \mathrm{~km}^{2}\right)$ is a $20 \mathrm{~m}$ water depth basin with a crescent shape (Fig. 2, Table 1). As illustrated in the bathymetric map, the presence of two round-shaped lacustrine basins suggests probable former maars settled below the current lake. Acoustic images (12 kHz) display a reduced accumulation of sediments, with a maximum thickness of $4 \mathrm{~m}$. Seismic profiles illustrate the development of a lacustrine drape characterized by few low amplitude but continuous reflections along with a transparent and chaotic lens capped by a thick reflector labeled R1 in Fig. 7 (Chapron et al., 2012).

The core MO10-H illustrates the sedimentary infill in this northern basin. The spectral map allows to identify three sedimentary units along the core (Fig. 8). At the top-core, the brownish unit U1 (0$16.5 \mathrm{~cm}$ depth) exhibits organic-rich sediments with $10 \%$ of TOC and elevated MS values. The OM fraction is made of a mix of terrestrial and algal material. Unit U2 (16.5-66 cm depth) shows decreasing MS values with depth and a slight decrease in organic content, dominated by terrigenous inputs of OM. This unit is separated from the unit U3 by a peak in MS at $66 \mathrm{~cm}$ depth. The down-core is characterized by the presence of an algal bloom layer with elevated TOC content. Within this unit, the presence of algal matter has been confirmed by palynofacies observation (Fig. 8). The seismic-to-core correlation underlines the correspondence between the MS peak at $66 \mathrm{~cm}$ depth and the reflector R1 identified on the seismic profile (Fig. 7).

\subsection{Lake Guéry}

Located at $1244 \mathrm{~m}$ a.s.l. on a basaltic plateau, Lake Guéry is the highest lake in the Mont Dore massif and drains a $6.5 \mathrm{~km}^{2}$ catchment area by a river on its west slope. To produce hydroelectricity, the construction of the dam in AD 1895 increased the lake-level to $5 \mathrm{~m}$ above its natural level. In consequence, the present-day lake surface reaches $0.26 \mathrm{~km}^{2}$ for a maximum water depth near $20 \mathrm{~m}$ (Fig. 2, Table 1). Within the lake, two acoustic surveys ( 4 and $14 \mathrm{kHz}$ source) display only gasrich sediments that precluded acoustic penetration and therefore impeded the observation of sedimentary units below the lake floor (Fig. 9).

Despite this lack of information, two short gravity cores collected in the central basin document the recent sedimentary fill. The multi-proxy approach reveals massive brownish sediments without visible sedimentary units (Fig. 12). Along core G11-B, the TOC content remains constant (9-10\%) and the organic fraction is dominated by terrigenous inputs throughout (Fig. 10). However, the X-rays analyses exhibit various features allowing us to unravel six sedimentary units within core G11-B (units B) and five within core G11-C (units C) (Fig. 10). These units are characterized by three main X-rays facies: (1) a homogeneous facies associated with high MS values in the top-cores (unit B1 between 0 and $1.5 \mathrm{~cm}$ depth and unit $\mathrm{C} 1$ between 0 and $6.5 \mathrm{~cm}$ depth); (2) faintly laminated facies (units B3, B5, C3 and C5) interrupted by (3) disturbed facies characterized by lenses and chaotic features. Three disturbed facies have been counted along core G11-B. From top to base, unit B2 (1.5-8.5 cm depth) shows chaotic lenses. At $13 \mathrm{~cm}$ depth, unit B4 (13-37 cm depth) displays a base underlined by elevated MS values. At the bottom of the core, unit B6 (100-123 cm depth) is characterized by low grey-levels and sedimentary disturbances on the X-rays facies. Core-to-core correlation links units B2 and B4 to units C2 and C4 identified in core G11-C, respectively. 

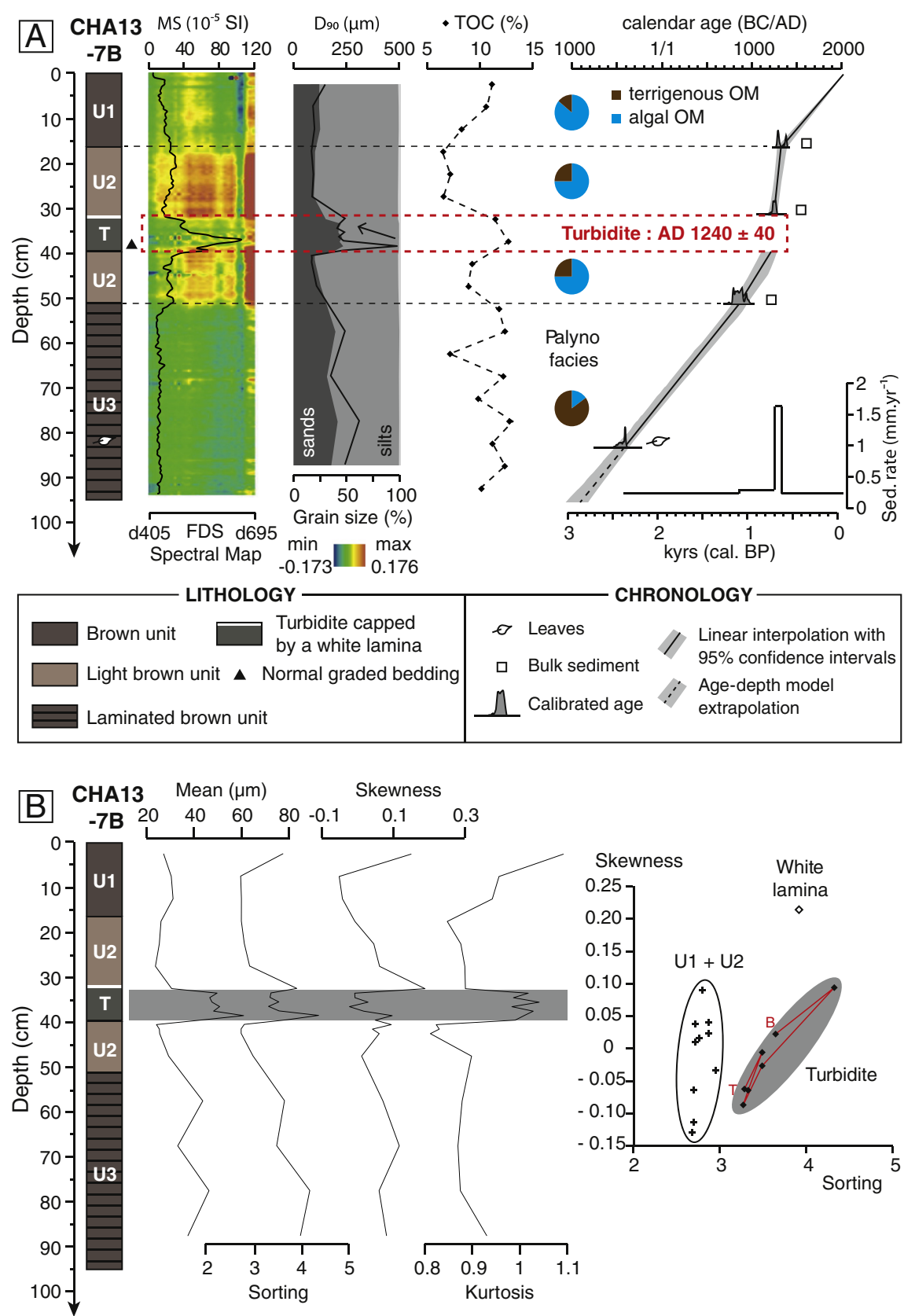

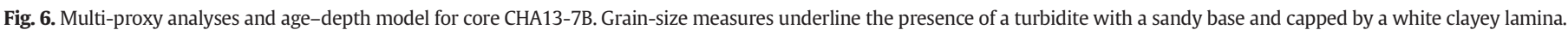

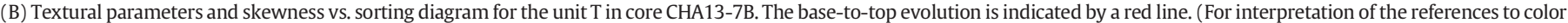
in this figure legend, the reader is referred to the web version of this article.)

\section{Discussion}

\subsection{Signatures and hydrodynamic processes of sedimentary events}

Investigations in volcanic lakes of the Mont Dore province underline the presence of several types of sedimentary events reflecting the rupture initiation and the hydraulic energy deployed during the transport and sedimentation (Mulder and Cochonat, 1996; Campos et al., 2014). The best examples of these processes are the contrasting textural signatures between sedimentary events identified in cores PAV12 (Fig. 4B) and CHA13-7B (Fig. 6B).

Following the classification of Mulder and Cochonat (1996), textural parameters of the green light unit identified in core PAV12 indicate a silty liquefied flow deposit and correspond to the top of the $4 \mathrm{~m}$ thick
MWD originating of the slope scar mapped at the edge of the plateau (Chapron et al., 2010) (Fig. 3). From base to top, the textural evolution of the silty liquefied flow deposit (Fig. 4B) do not support a reducing energy, as the skewness values remain high during the deposition of the top of this unit (Bertrand et al., 2008). The chaotic evolution suggests fluctuations in the depositional dynamic (Campos et al., 2014). In a maar like Lake Pavin, this chaotic evolution could be the consequence of a prolonged motion of the water column impeding a finegrained homogeneous suspension. In a recent study, Chassiot et al. (2016) connected this silty liquefied flow deposit to the collapse of the edge of the plateau (Fig. 3). Constrained in a deep flat basin surrounded by steep walls, the flow resulting from this collapse may have not been transported over a long distance, but likely reflected on the southern side. Therefore, the bowl-shaped morphology of Lake 


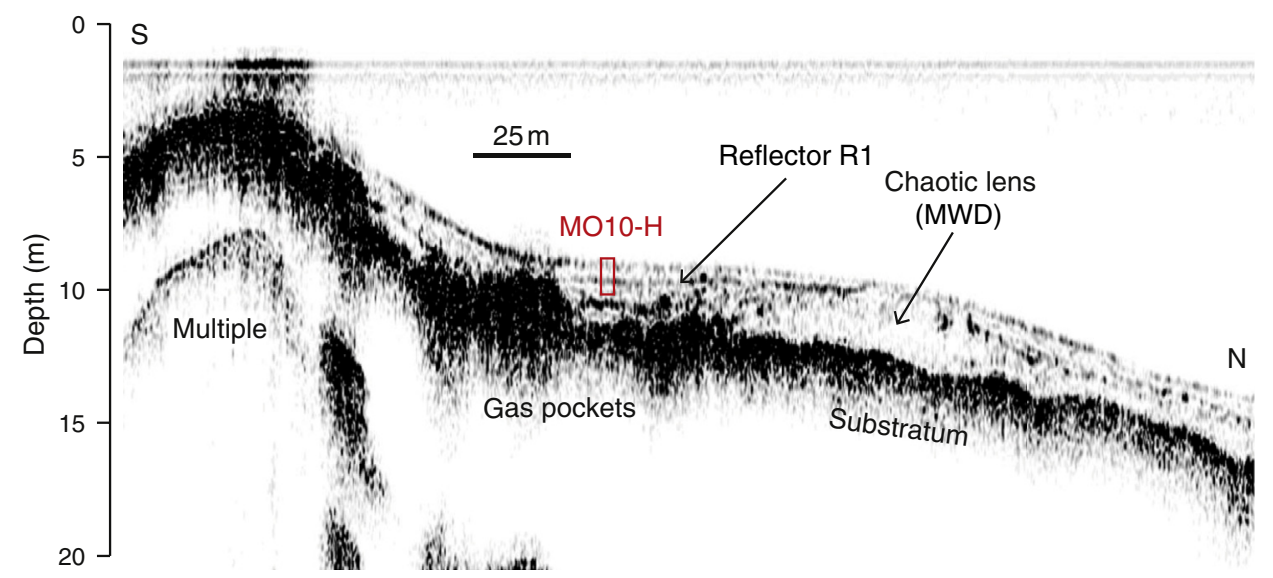

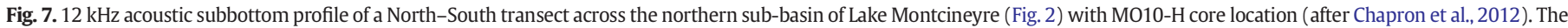
transparent to chaotic lens reflects a Mass-Wasting Deposit, here capped by a high amplitude reflector labeled R1.

Pavin, in contrast to large alpine lakes or marine environments, may explain the chaotic base-to-top evolution in the textural parameters of this deposit (Fig. 4B).

The volume of reworked sediment can be roughly estimated considering the deep flat basin as the sedimentation surface $\left(80,000 \mathrm{~m}^{2}\right)$ (Fig. 11). The total thickness of the MWD exceeds $4 \mathrm{~m}$ in core PAV12 (Chassiot et al., 2016) (Fig. 3). The maximum volume of reworked sediment can thus be estimated to $320,000 \mathrm{~m}^{3}$. Among this volume, $56,000 \mathrm{~m}^{3}$ may correspond to the $70 \mathrm{~cm}$ thick silty deposit identified at the top of the MWD. In core CHA13-7B, the sandy base and the fining upward sequence identified in unit $\mathrm{T}$, in addition to a white lamina at its top, constitute evidences for a sedimentary event deposited during one short-term episode of turbidity current (i.e., turbidite, e.g., St-Onge et al., 2004; Strasser et al., 2013). The base-to-top decrease in sorting and skewness values indicates a decreasing energy during deposition at core site (Fig. 6B). According to acoustic images accuracy in the vertical resolution $( \pm 10 \mathrm{~cm})$, this turbidite could match the reflector identified just below the lake floor (Fig. 5). In addition, its position downslope from the reworked sediment may reflect the evolution in the transport mode of one single event, from a proximal debris flow on the slopes to a distal low-density turbidity current in the deep basin (Fig. 5). Therefore, a transport by suspension during a turbulent flow was probably initiated downslope after the failure of slope sediments. Unlike Lake Pavin, gentler slopes combined to a greater distance from the failure area may explain this signature in textural parameters, with a finingupward sequence deposited during a reducing unidirectional turbulent flow at core CHA13-7B location. However, the absence of clay enrichment in the white lamina does not relate it to a fine-grained

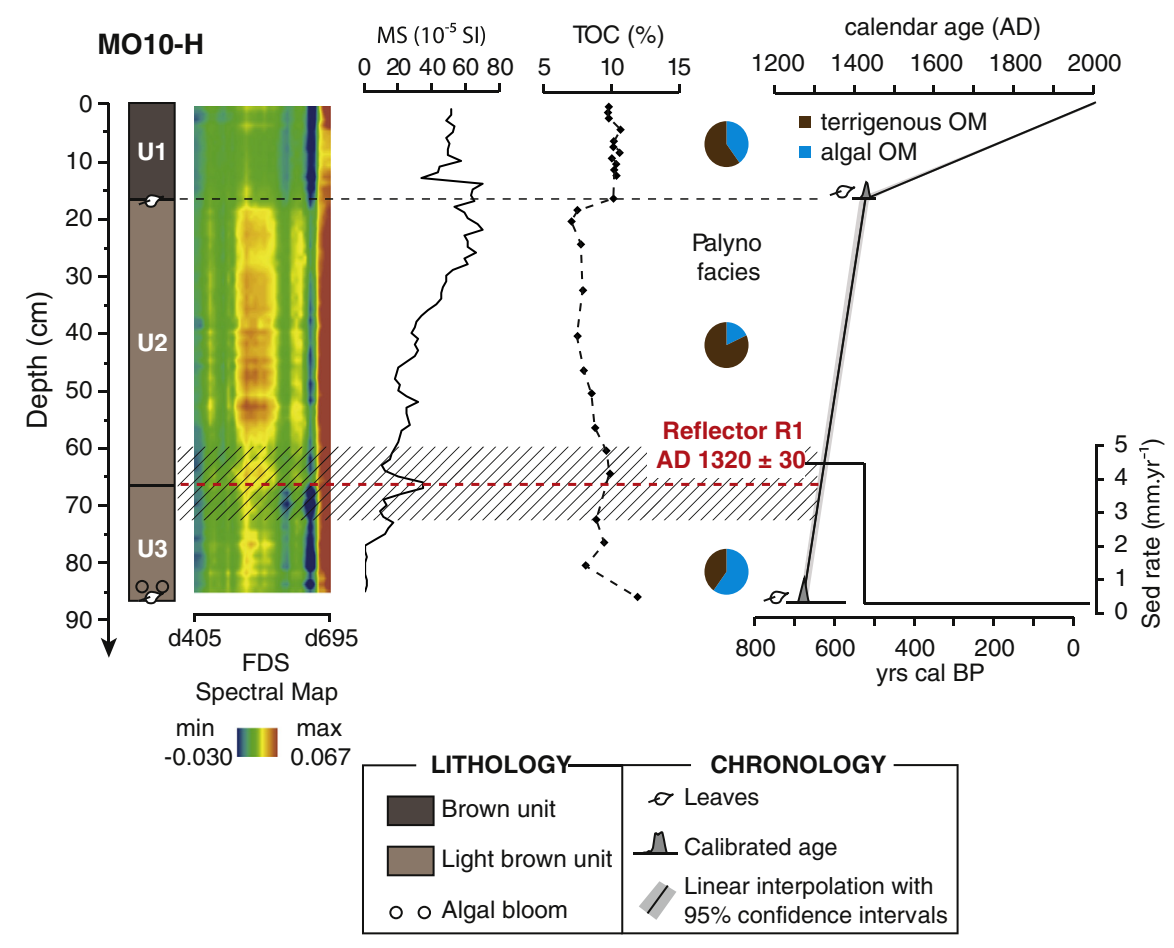

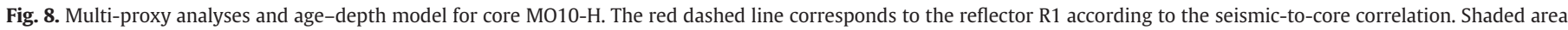

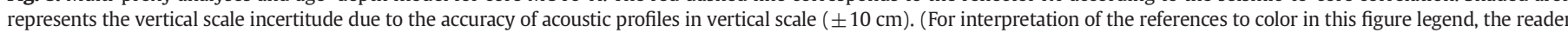
is referred to the web version of this article.) 

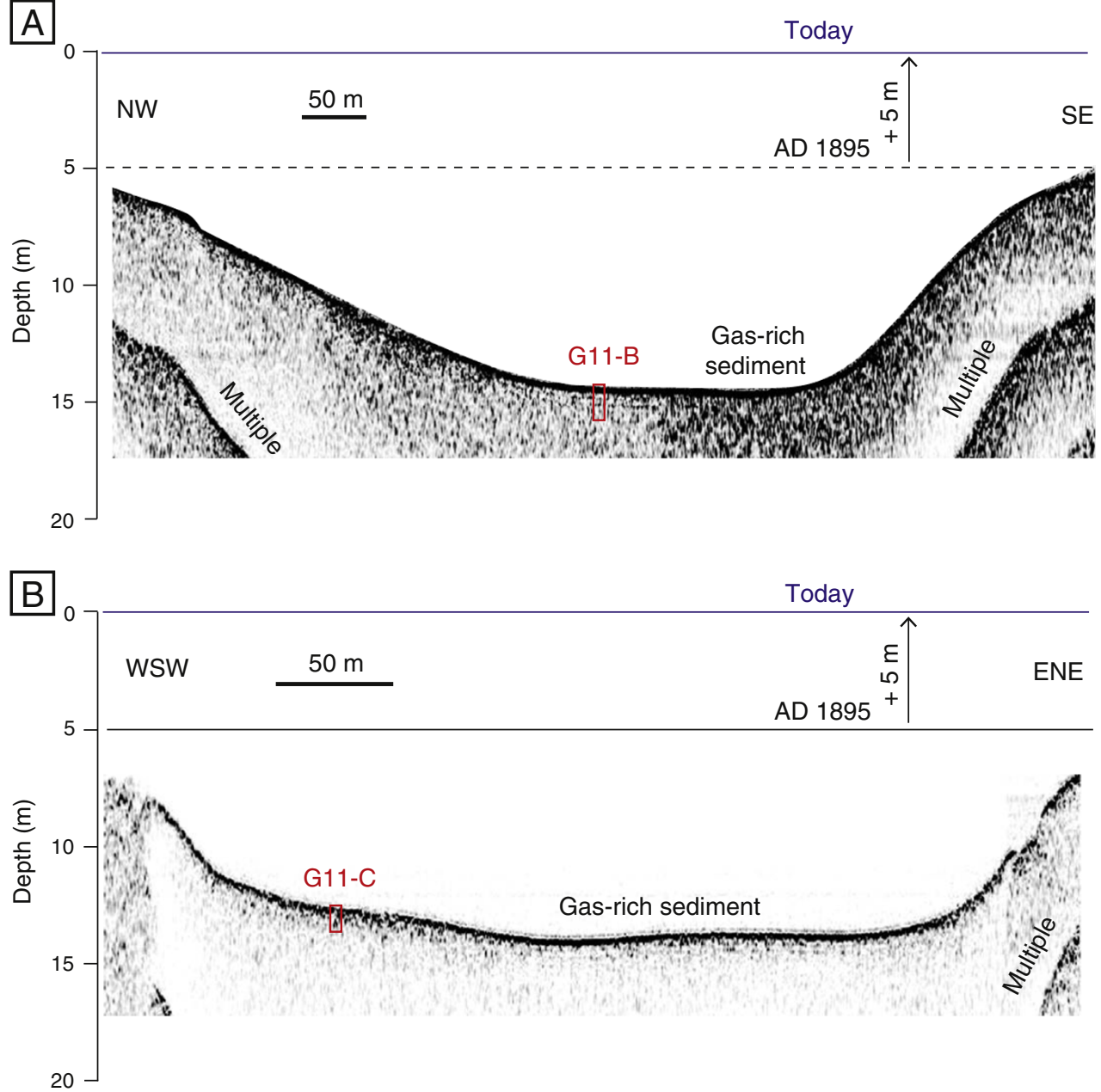

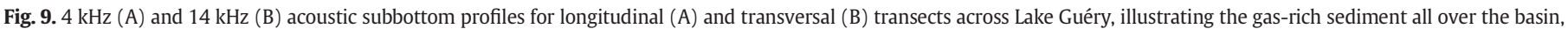
precluding the observation of sedimentary infill geometry.

homogenous suspension, but likely to a diatom bloom in response to enhanced nutrient inputs in the deep basin during the turbulent flow. The acoustic profiles performed in the southwestern side indicate a $1.5 \mathrm{~m}$ thick chaotic facies corresponding to reworked sediment on the axis of the inflow (Fig. 5). This facies has been mapped on a large area along the southwestern side of the lake, suggesting a large volume $\left(150,000 \mathrm{~m}^{3}\right)$ of reworked sediments (Fig. 11).

In Lake Montcineyre, only one acoustic image displays a $50-\mathrm{m}$ long chaotic lens, an acoustic feature frequently associated with reworked sediments aggregated into a Mass-Wasting Deposit (MWD, e.g., Moernaut et al., 2007). This suggests a small volume of sediment with a limited extension within the basin. According to the bathymetric map, source areas probably correspond to the steep flanks of the Montcineyre volcano, east side of the lake (Fig. 11).

In Lake Guéry, the X-rays radiographies highlight disturbed facies with lenses and chaotic features that reflect sediments deposited downslope after gravity reworking processes (MWD, e.g., Beck, 2009). The absence of acoustic penetration below lake floor prevents to estimate the geometry of these deposits, but the steep slopes on the northwestern side of the lake, in the axis of the river inflow, may correspond to the source area for MWDs identified in the deep basin (Fig. 11).

\subsection{Chronology of sedimentary events}

As detailed in Chassiot et al. (2016), we assume a uniform diatomaceous sedimentation across the deep flat basin of Lake Pavin to constrain the age of the silty liquefied flow deposit identified in core PAV12. Therefore, the revised varve counting performed on core FC01 (Stebich et al., 2005; Schettler et al., 2007) has been translated to PAV12 (Fig. 2). Moreover, two radiocarbon dates on leaf debris sampled in piston core PAV12 and nearby gravity-core PAV09-B1 (Fig. 2, Table 2) match the varve chronology and thus support the age of the silty liquefied flow deposit, here estimated to ca. cal. AD $1280 \pm 20$ (Chassiot et al., 2016).

In core CHA13-7B, the predominance of algal-derived compounds (75-85\%) in the organic fraction of units U1 and U2 (Fig. 6) suggests a negligible "old carbon" effect. Calibrated radiocarbon ages of the three bulk sediments sampled within these units (Table 1) thus appears in order to compute an age-depth model. With this method, the turbidite identified within unit $\mathrm{U} 2$ has been dated to cal. AD $1240 \pm 40$ (Fig. 6).

In core MO10-H, the age-depth model displays a high sedimentation rate during the deposition of the reflector R1. This reflector has been dated to cal. AD $1320 \pm 30$ (Fig. 8), considering uncertainty of $10 \mathrm{~cm}$ in the vertical resolution of the seismic profile. Thereby, a similar age can be inferred for the MWD identified downslope and capped by this reflector (Fig. 7).

In cores G11-B and G11-C, we assume the onset of homogeneous units at top-cores is connected to the lake-level rise after dam construction in AD 1895 (Fig. 10). Thereafter, this chronological information has been used to constrain the chronology of the upper units. In addition of two AMS radiocarbon dating sampled in laminated sediments of G11-B 


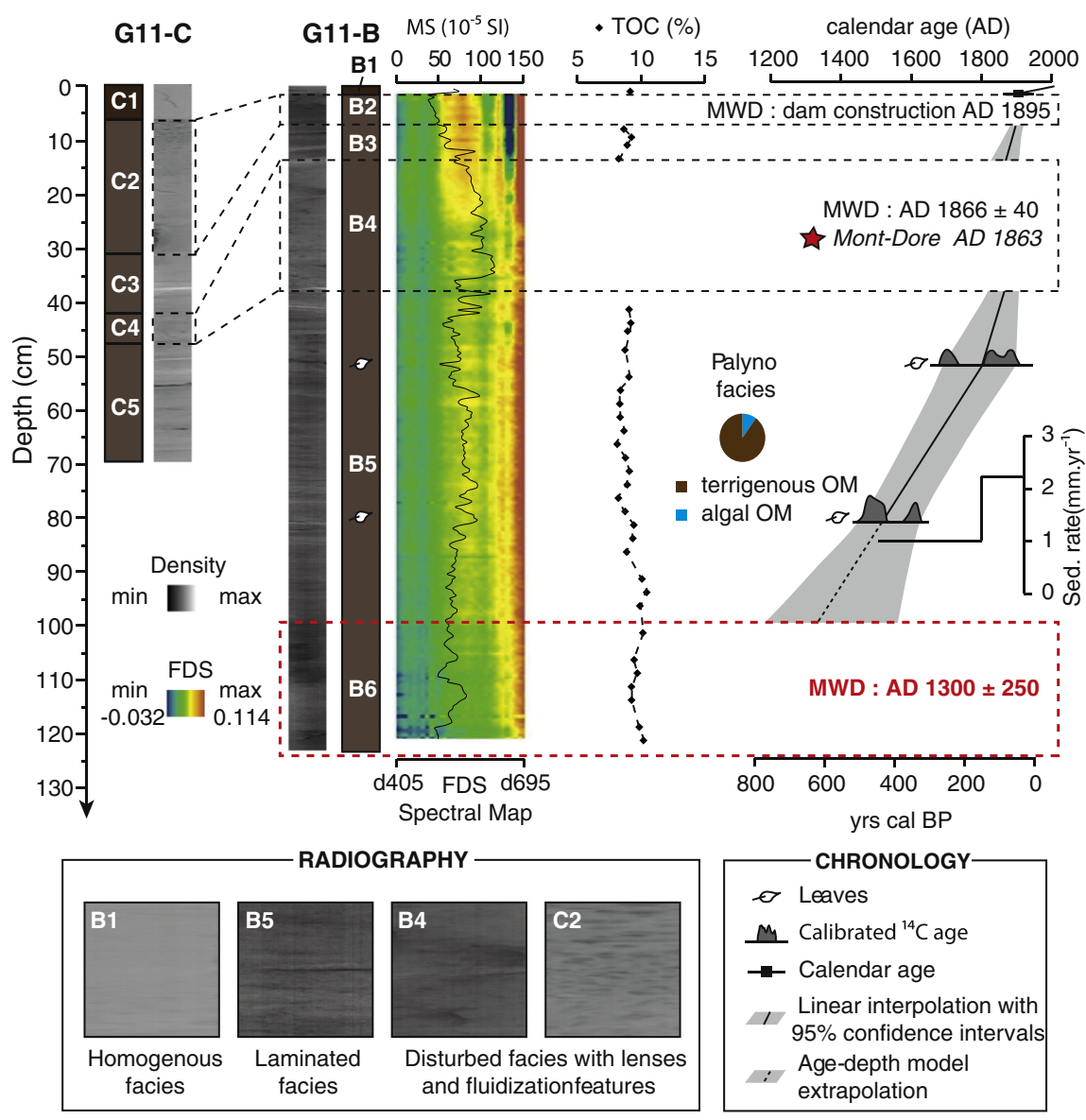

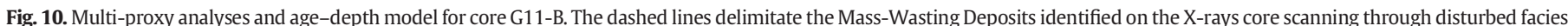

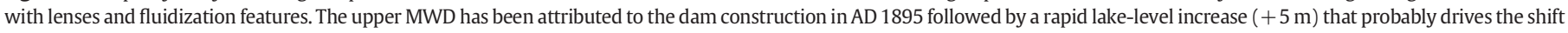
observed on X-rays facies in the top-cores (B1 and C1).

(Table 2), we computed an age-depth model once the MWD removed. From top to base, the ages of MWDs have been estimated to cal. AD 1895 (B2 and C2), cal. AD $1860 \pm 40$ (B4 and C4) and cal. AD $1300 \pm 250$ (B6). The later has been calculated by extrapolating the age-depth model and the $95 \%$ confidence intervals (Fig. 10).

Within the four lakes, a series of 6 sedimentary events has been dated over the last 700 years. In addition to the 2 earthquaketriggered turbidites identified in Lake Pavin sedimentary record (Chassiot et al., 2016), this total increases to 8 sedimentary events occurring within the area for the last millennium. Their occurrence in time highlights the late XIII ${ }^{\text {th }}$ and the XIX ${ }^{\text {th }}$ centuries as two periods with synchronous events in at least two lakes (Fig. 12).

\subsection{Triggering factors of sedimentary events}

In lacustrine environments, sedimentary events such as MWD and/or turbidite can be triggered by sediment overloading, lakelevel fluctuations, waves, snow avalanches, rock falls, gas discharge or earthquakes (e.g., Monecke et al., 2004; Girardclos et al., 2007; Strasser et al., 2013). The following slope failure will cause a gravity-driven transport of reworked material. Usually, the good matching between sedimentary events in lakes and an historical earthquake in the vicinity increases the likelihood for earthquaketriggered deposits, but this method is often limited by the availability and the accuracy of historical reports that rarely goes beyond the last millennium. In Holocene records, the occurrence of synchronous deposits in disconnected basins is a recognized argument for widespread triggering mechanisms such as earthquakes (e.g., Strasser et al., 2013; Moernaut et al., 2014; Pouderoux et al., 2014; Chapron et al., 2016). However, the use of lacustrine archives remains limited by the ability of lake sediments to record earthquakes. When a tectonic event occurs, both magnitude and lakeepicenter distance have to be considered in the generation of slope failures and the following deposition of mass-movement deposits. On the one hand, the increasing lake-epicenter distance tends to reduce the lake sensitivity to earthquakes (Moernaut et al., 2007). On the other hand, the more the magnitude increases, the more the lake will be sensitive to seismic ground motion. However, this concept is highly dependent of seismic wave propagation within the studied area, which can be amplified by topographic effect in mountain ranges.

\subsection{Human-induced and earthquake-triggered deposits in the XIX ${ }^{\text {th }}$ century}

The spatio-temporal distribution of sedimentary events in lakes highlights the late XIX ${ }^{\text {th }}$ century as a period with four events identified in two lakes (Fig. 12). Two turbidites have been previously inventoried in the deep basin of Lake Pavin (AD $1825 \pm 20$ and AD $1860 \pm 20$, see Chassiot et al., 2016 for details), in addition to two MWDs identified in Lake Guéry (AD $1866 \pm 40$ and likely AD 1895). At this site, the most recent MWD has been attributed to the lake-level rise following the dam construction on the basis of two clues. First, the onset of a homogenous sedimentary unit above this MWD must reflect a drastic environmental change probably induced by the increase of water depth $(+50 \%)$ and lake surface $(+56 \%)$. Second, change in pore-fluid 


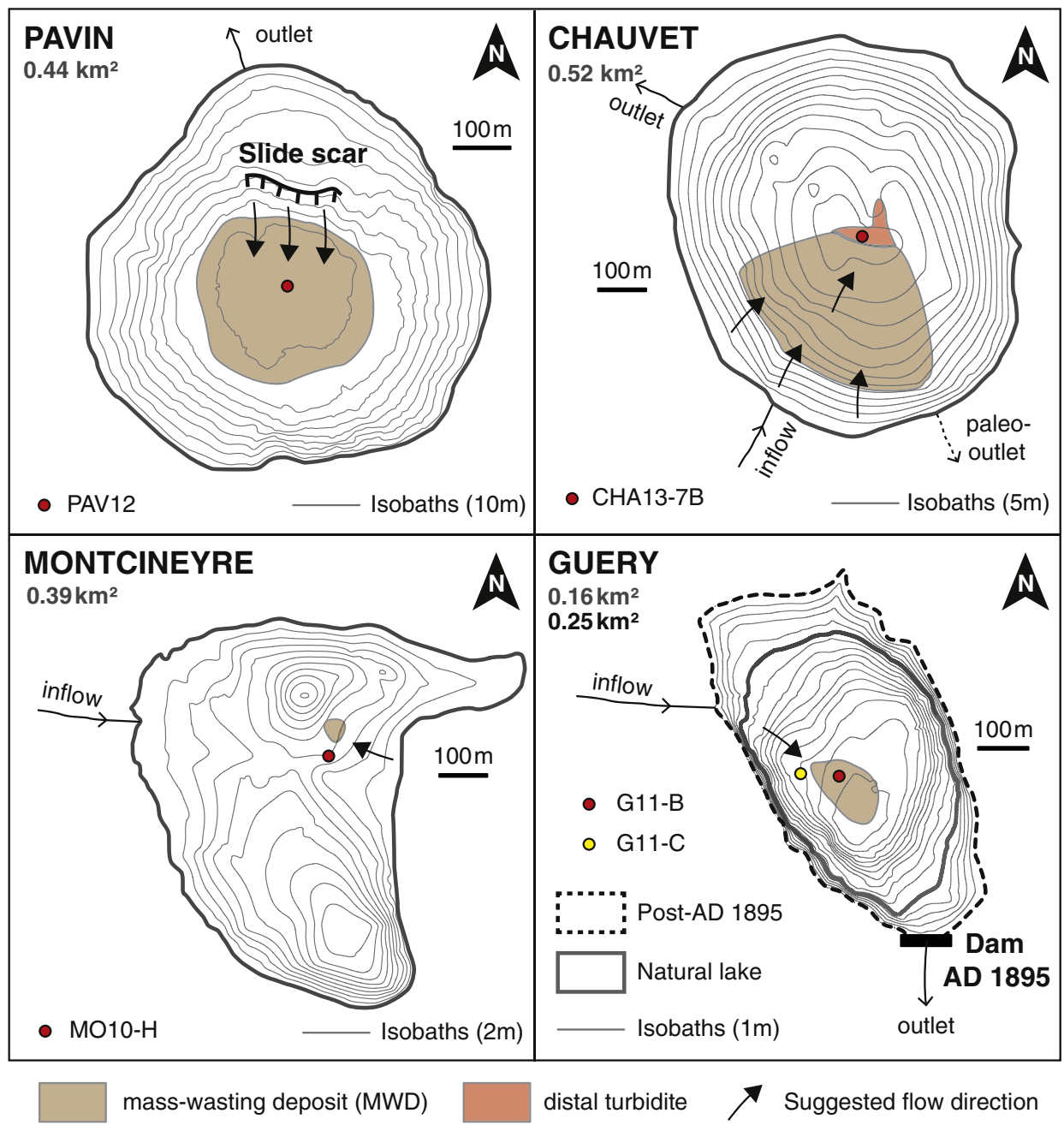

Fig. 11. Source areas and estimated surface for the AD 1300 earthquake-triggered sedimentary events in lakes Pavin, Chauvet, Montcineyre and Guéry.

pressure induced by such an abrupt lake-level fluctuation is a recognized trigger for slope failure and subsequent sedimentary units destabilization (Anselmetti et al., 2009). The events dated AD $1860 \pm 20$ (Lake Pavin) and AD $1866 \pm 40$ (Lake Guéry) gather into the same time window and thus may coincide with the occurrence of the 1863 earthquake located at Mont Dore (Fig. 1B). The proximity of its epicenter compared to both lakes $(<10 \mathrm{~km})$ may indicate a common tectonic trigger for these two sedimentary events, despite a weak moment of magnitude ( $\mathrm{Mw}=3.38 \pm 0.62$ after Stucchi et al., 2013) (Fig. 12). The occurrence of a larger earthquake in $\mathrm{AD} 1892(\mathrm{Mw}=5.50 \pm 30$ and Io $=$ VII) only $30 \mathrm{~km}$ east in the South Limagne fault can also be an alternative for triggering subaquatic landslides in the Mont Dore region (Chassiot et al., 2016) (Fig. 1B). Similarly, the turbidite dated cal. AD $1825 \pm 20$ in Lake Pavin is expected to have been triggered by a tectonic event, but there again, the accuracy in the age-depth model precludes to define a single source, as the recurrence time of earthquakes during this period was very short. For this event, potential candidates could be either the AD 1844 (unknown Mw and Io $=V^{1} 1 / 2$ ) or the AD 1833 ( $\mathrm{Mw}=5.04 \pm 0.30$ and Io $=$ VII $)$ seismic events that occurred at Chambon-sur-lac $(<15 \mathrm{~km})$ and Issoire $(30 \mathrm{~km})$, respectively (Fig. 12). In the same manner, the event occurring below the Chaînedes-Puys in AD $1857(\mathrm{Mw}=4.86 \pm 0.30$ and $\mathrm{Io}=\mathrm{V} 1 / 2$ ) could match one of the previously mentioned events, but the lake-epicenter distance is much farther (>30 km) by comparison with other similar events reported in the $\mathrm{XIX}^{\text {th }}$ century.
5.5. Lacustrine records of an undocumented paleo-earthquake around $A D$ 1300

Further back in time, four deposits have been identified within lakes Pavin, Guéry, Chauvet and Montcineyre (Fig. 11). Exception made of the one dated in lake Guéry with an extrapolation of the age-depth model, the dating accuracy provides reliable chronological constrains about their synchronicity during the late XIII ${ }^{\text {th }}$ century or the early XIV ${ }^{\text {th }}$ century (Fig. 12). However, no seismic activity neither in AHEAD database (Stucchi et al., 2013) nor in other historical documents (Lambert et al., 1997) has been reported during this medieval period. Despite this fact, the gathering of these events around AD 1300 suggests a common regional trigger. The likelihood for a tectonic triggering is therefore very high for this event identified in disconnected basins over a large area.

In the absence of historical reports about this event, a large earthquake like those documented near the Limagne fault is unlikely. However, a weaker paleo-earthquake such as the AD 1863 in Mont Dore event could be a possibility. To support this hypothesis, recent archeological investigations on the neighboring Murol castle (Fig. 1B) have revealed failures and collapses estimated to the late XIII ${ }^{\text {th }}$ century (Allios, 2015). The temporal distribution of seismic events in the area does not display single events for the last millennium, but clusters of tectonic events occurring in short time windows (Fig. 12). Consequently, the occurrence of synchronous MWDs in disconnected basins as it was in $\mathrm{AD} 1300$ highly suggests a (cluster of) regional earthquake(s) as a 

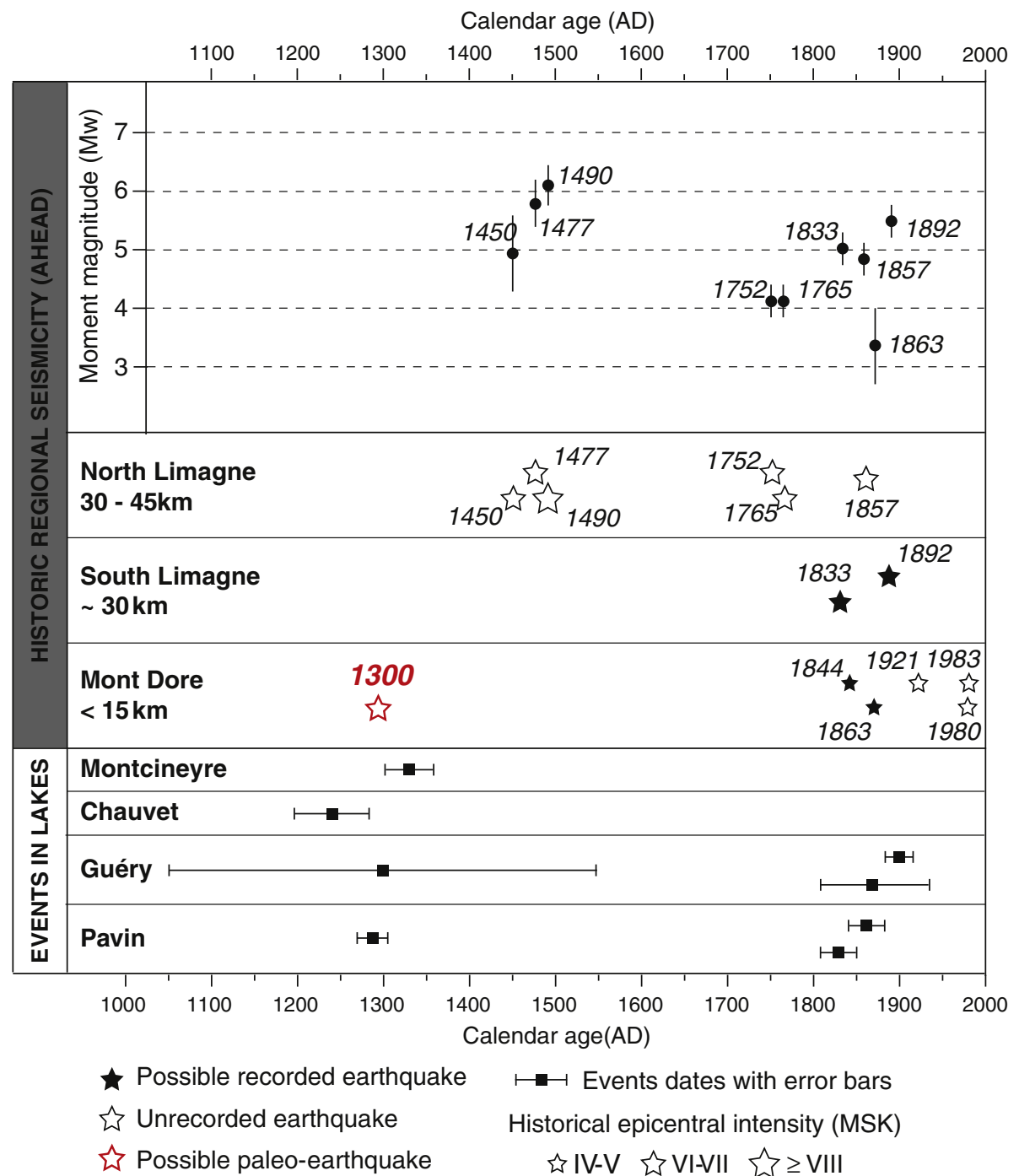

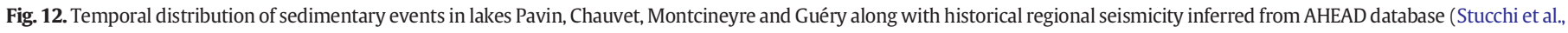
2013). Additional data are taken from Chassiot et al. (2016). Epicenters are presented according to their intensity, their moment magnitude (Mw) and their distance to lakes.

trigger for simultaneous slope failures in lakes Pavin, Guéry, Chauvet and Montcineyre.

Chassiot et al. (2016) evaluated Lake Pavin sensitivity to earthquakes and suggested this lake can record earthquakes with epicentral intensity of $\mathrm{V}$ in a radius of $15 \mathrm{~km}$. This maximum lake-epicenter distance has been coupled to the radial distance between Lake Guéry and the $\mathrm{AD} 1863$ earthquake epicenter to define an area where the $\mathrm{AD}$ 1300 earthquake epicenter must have been situated (Fig. 13). Within this seismogenic area, this epicenter location is supported by the occurrence of earthquakes during the XIX ${ }^{\text {th }}$ century and the absence of earthquake-induced deposits along a SW-NE transect in lakes Aydat (Lavrieux et al., 2013), Chambon (Macaire et al., 1997) and Crégut (Chassiot, 2015). Further investigations on nearby maar lakes Servières and La Godivelle-d'en-Haut (Bastin et al., 1991; Juvigné, 1992) may greatly improve the scope of this medieval event.

\subsection{Lake sensitivity to earthquakes}

Apart from the external parameters related to the tectonic event (i.e., magnitude, intensity and lake-epicenter distance), lake sensitivity to earthquakes is a function of several morphological, sedimentological and limnological parameters that play a key-role in sediment stability. These parameters are reviewed thereafter, with the aim to explain the specificities of each lake in our setting.
In the first case, lake morphology is assumed to be the primary parameter, as sediments settled on steep slopes are more susceptible to be driven by gravity reworking processes than sediments buried in flat basins. In volcanic regions, the lacustrine morphology is mainly associated with lake origin. The bowl-shaped maar lakes display high depth-area ratios with steep slopes (Anselmetti et al., 2009; Chapron et al., 2010; Chassiot et al., 2016) as opposed to volcanic-dam lakes which generally have gentler slopes (Lavrieux et al., 2013) (Table 1, Fig. 2). Such contrast in the geomorphological setting between lakes may explain the large MWD and its associated distal turbidite identified across the Lake Chauvet in AD 1300 (Figs. 5 and 6), as well as the synchronous large slope failure and the associated slump in the deep basin of Lake Pavin (Figs. 3 and 4). Similarly, the thin turbidites described in the basin during the XIX ${ }^{\text {th }}$ century probably would have not been recorded in another geomorphological context (Chassiot et al., 2016).

The nature of sediment has also to be considered during a seismic shaking. Fine-grained but organic-rich sediments have been reported in the four studied lakes. During sedimentation, the burial of organic matter may lead to the accumulation of gas within the sedimentary units, as observed in the deep basins of Lake Pavin and across Lake Guéry (Figs. 3 and 9). In such a context, the earthquake shaking may alter the sediment stability by a sudden gas release associated with fluidization features and thus favoring the generation of MWDs (Chapron 


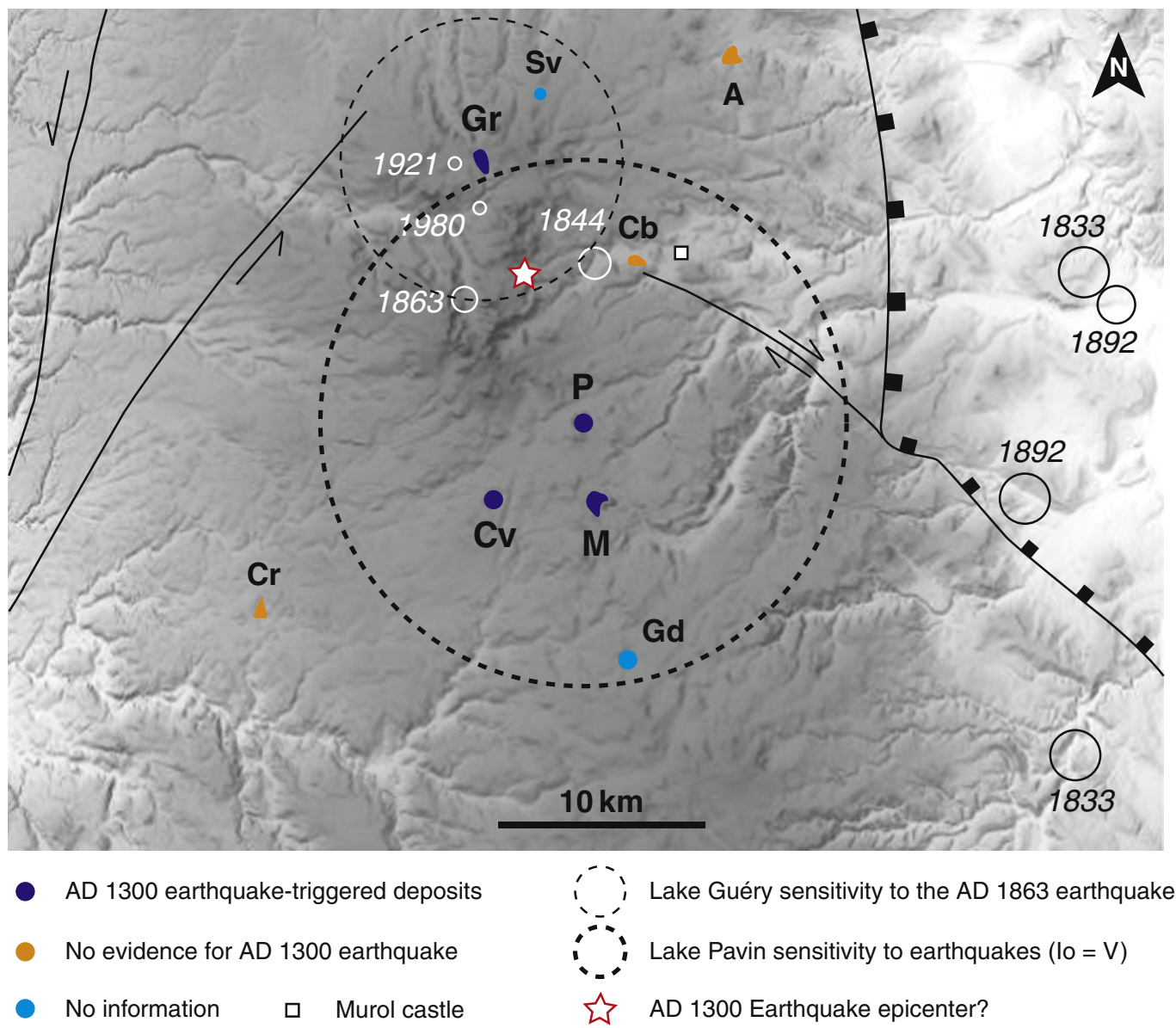

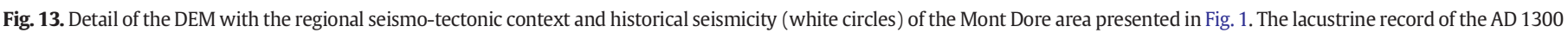

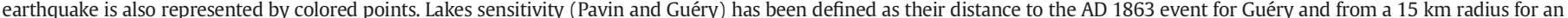

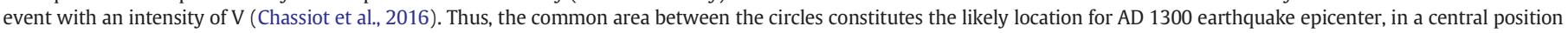
amongst lakes where it has been recorded. (For interpretation of the references to color in this figure legend, the reader is referred to the web version of this article.)

et al., 2004; Moernaut et al., 2007). In the specific setting of Lake Pavin, the dominant in-situ diatomaceous sedimentation develops unconsolidated material draping steep slopes that can also be remobilized during tectonic events (Chassiot et al., 2016).

Lake-level fluctuations can also modify the interstitial water pressure within the sedimentary units and thus alter sediment stability. Variations in lake-level can be a function of the hydrological balance (Precipitation/Evaporation ratio) under climatic forcing over long periods (Anselmetti et al., 2009). In Lake Pavin, the former lake drainage by the failure of the crater rim in AD 600 led to an abrupt drawdown of ca. $9 \mathrm{~m}$ that may have substantially enhanced its capacity to record the subsequent earthquakes (Chassiot et al., 2016).

Finally, high sediment load may also favor the occurrence of slope failure in large and small lakes (Girardclos et al., 2007; Wilhelm et al., 2015). Despite the absence of significant deltas in the small lakes across the Mont Dore, an increase in sediment fluxes may lead to local sediment overload on the slopes which can, in case of a seismic event, slide to generate MWDs downstream. In nearby lakes Montcineyre and Chauvet, an increase in sedimentation rates at the time where the MWDs occurred (Figs. 6 and 8) can be noticed. Across these two lakes, age-depth models highlight the medieval times (ca. AD 850-AD 1400 ) as a period with high sedimentation rates, probably in relation with increased human activities in the catchment, as attested by other studies in close Lake Aydat (Lavrieux et al., 2013). Likewise, in Lake Guéry, the permanent river drains a relatively large catchment area and feed the lake with terrestrial supplies. There again, the increase in the sedimentation rates at G11-B site in Lake Guéry may reflect a human-induced increased runoff in the catchment since the early $\mathrm{XIX}^{\text {th }}$ century that may have favored the recording of the AD 1863 event (Fig. 10). Recent studies focusing on alpine lakes pinpoint sedimentation patterns as important factors controlling the lake sensitivity to earthquakes, mainly controlled by climate-induced major environmental changes over the Holocene (Chapron et al., 2016). In contrast, the Mont Dore province exhibits two examples (i.e., Lake Montcineyre and Lake Chauvet) of human-induced changes in sedimentation rates. In these cases, it seems that the human impact on soil erosion during medieval times greatly increased the sediment load, which favored the formation of unconsolidated sediment removed during a regional seismic shaking near AD 1300. The decrease in the sedimentation rate observed in these two systems at the beginning of the $\mathrm{XV}^{\text {th }}$ century, probably driven by land-use evolution within catchments, may explain the lack of earthquake-induced deposits during the XIX ${ }^{\text {th }}$ century. On the contrary, Lake Pavin and Lake Guéry display higher sedimentation rates which can facilitate the record of subsequent earthquakes at this period.

In consequence, lake sensitivity to earthquakes is a combination of external (i.e., related to the tectonic event) and internal (i.e., specific to each lake) factors. Moreover, lake sensitivity to earthquakes can be pictured as an evolving concept over time. Because lake sensitivity can be significantly altered by short-term human impact and/or long-term climatic fluctuations in sedimentary load, these two factors need to be considered for future perspectives focusing on these natural seismographs, which have major implications for paleoseismology and seismic hazard assessment. 
5.7. Implications for ancient landslides and historical seismicity in the region

The regional event stratigraphy of earthquake-triggered deposits in lake sediments offers the opportunity to revisit former studies reporting subaerial and subaquatic landslides with new insights about historical seismicity in the Mont Dore volcanic area.

The recent volcanic activity in the Mont Dore produced complex geomorphological structures made of potentially unstable materials and thus susceptible to landslides and collapses (Vidal et al., 1996). Volcanic instability can be further amplified when tectonic events occur. Former subaerial debris avalanches and subaquatic slides documented back to $2600 \mathrm{BP}$ bring insights on the regional susceptibility to gravitational processes under potential seismic stress. As an example, the historical Dent-du-Marais collapse resulting in the formation of Lake Chambon II ca. 2600 years ago is one example of large massmovement $\left(7 \times 10^{6} \mathrm{~m}^{3}\right)$ initiated on the edge of a cliff and probably triggered by a prehistoric earthquake (Vidal et al., 1996; Macaire et al., 1997). In such a volcanic setting characterized by fragile bedrock, even a small event can result in massive landslides. However, synchronous subaquatic landslides were not observed in the long-term sedimentary archives of lakes Aydat (Lavrieux et al., 2013) and Pavin (Chassiot et al., 2016), underlining either the very local impact of such tectonic event or the limited lake sensitivity to seismic shaking at this time, if a seismic trigger is attested. Inversely, two MWDs have been described in these basins, at ca. AD 180 for Lake Aydat and ca. AD 600 for Lake Pavin, but their origin still remains unclear.

The complex relationship between tectonic activity and the occurrence of slope failure in lakes can also be illustrated by the reverse effect, when documented historical earthquakes are not recorded within the lacustrine archives. Best examples are the well described largest earthquakes ( $\mathrm{Mw}=5.80 \pm 0.46$ in $\mathrm{AD} 1477$ and $\mathrm{Mw}=$ $6.11 \pm 0.31$ in AD 1490 after Stucchi et al., 2013) occurring in the North Limagne (Fig. 1B, Lambert et al., 1997), which have surprisingly never been reported in lake sediments across the Mont Dore province. By comparison with closer seismic events, the average $30 \mathrm{~km}$ lake-epicenter distance could explain this lack of sedimentary evidence but it is recognized that source areas for seismic recording may extend more widely (Nomade et al., 2005; Chapron et al., 2006; Wilhelm et al., 2015). The absence of co-seismic sediment disturbance at this period may be a combination of reduced lake sensitivity and a lack of knowledge about ground motion propagation in this volcanic context. Another explanation could be linked to the historical record of a former earthquake only 200 years earlier in at least four lakes (i.e., Pavin, Chauvet, Montcineyre and Guéry). Due to limited sedimentation rates, the sedimentary reload may have not been sufficient to accumulate unstable sediments. Therefore, the record of earthquake-triggered deposits may inhibit the lake sensitivity to forthcoming events (Moernaut et al., 2007). The northernmost maar lake Gour de Tazenat (Juvigné and Bastin, 1995; Juvigné and Stach-Czerniak, 1998), close to the Limagne fault, appears to be an essential target to better assess the scope of these large earthquakes (Fig. 1B).

\section{Conclusions}

Recent limnogeological investigations conducted on small volcanic lakes of the Mont Dore province reveal the occurrence of massmovements deposits through a large panel of sedimentological and geophysical evidences. This regional event stratigraphy highlights the tectonic factor as an essential trigger for reworking significant volumes of sediment over the last millennium. Over the Mont Dore area, the description and dating of synchronous MWDs in lakes Pavin, Chauvet, Montcineyre and Guéry underlines the existence of a medieval earthquake, not listed to date, occurring around AD 1300. According to the regional sedimentary records, the likely epicenter of this paleo- earthquake could be located in the heart of the Mont Dore volcanic province. Despite the occurrence of the largest events during the end of the $\mathrm{XV}^{\text {th }}$ century, lakes in the Mont Dore area have not been affected by seismic disturbance until the XIX ${ }^{\text {th }}$ century, when earthquakes located either in the Limagne or in the Mont Dore area triggered synchronous slides in lakes Pavin and Guéry.

These results also demonstrate the possibility of using the sediments of small lacustrine basins as natural seismographs, even in an area of low to moderate tectonic activity. The correlation between MWDs and historical seismicity bring new insights on lake sensitivity to seismic disturbance as a balance between external and internal parameters. External factors are related to the earthquake-induced ground motion diffusion depending on several parameters such as the magnitude, lake-epicenter distance and the regional seismotectonic context. On the other hand, internal factors are directly connected to the lake whose sediments can be used as natural seismographs. Through a wide range of lacustrine systems, we emphasize slopes, nature of sediment, lake-level fluctuations and sedimentary load as essential factors of lake sediments ability to record tectonic events.

The present study remains one of the few paleoseismologic studies performed in a volcanic intraplate domain. In contrast to high-altitude alpine lakes, it seems that the sensitivity of small volcanic lakes from the Mont Dore province is also related to short-term human-induced changes in sedimentation rates. The variable lake sensitivity to earthquakes is essential to understand the seismic record within this region once more populated and needs to be considered for future investigations focusing on paleoseismology, in particular in tectonically active districts where human impact can be significant.

\section{Acknowledgments}

Coring operations in Lake Pavin were financed by the CNRS-INSU in the framework of the DICENTIM project directed by Anne-Catherine Lehours. Léo Chassiot benefited of a PhD grant from Région Centre. Authors thank Grégoire Ledoux, Anaëlle Simonneau and OSUC master students for the help during field campaigns and Dominique Allios for complementary information about tectonic imprints in the Murol Castle. Authors are also grateful to editor Jasper Knight and reviewer Jean-Noël Proust whose thoughtful comments significantly improve the initial version of this manuscript.

\section{References}

Allios, D., 2015. Murol, la Forteresse Muette. Presses Universitaires de Rennes (216 pp.). Anselmetti, F.S., Ariztegui, D., De Batist, M., Gebhardt, A.C., Haberzettl, T., Niessen, F. Ohlendorf, C., Zolitschka, B., 2009. Environmental history of southern Patagonia unravelled by the seismic stratigraphy of Laguna Potrok Aike. Sedimentology 56 873-892.

Avşar, U., Hubert-Ferrari, A., Batist, M.D., Fagel, N., 2014. A 3400 year lacustrine paleoseismic record from the North Anatolian Fault, Turkey: implications for bimodal recurrence behavior. Geophysical Research Letters 41, 377-384.

Avşar, U., Hubert-Ferrari, A., De Batist, M., Schmidt, S., Fagel, N., 2015. Sedimentary records of past earthquakes in Boraboy Lake during the last ca 600 years (North Anatolian Fault, Turkey). Palaeogeography, Palaeoclimatology, Palaeoecology 433, 1-9.

Baize, S., Cushing, E.M., Lemeille, F., Jomard, H., 2013. Updated seismotectonic zoning scheme of Metropolitan France, with reference to geologic and seismotectonic data. Bulletin de la Société Géologique de France 184, 225-259.

Bastin, B., Gewelt, M., Juvigne, E., 1991. A propos de l'âge et de l'origine des tephras tardiglaciaires T4 et T5 de Godivelle-Nord (Massif Central, France). Annales de la Société Géologique de Belgique 113, 165-178.

Baumont, D., Scotti, O., 2011. The French Parametric Earthquake Catalogue (FPEC) based on the best events of the SisFrance macroseismic database-version 1.1. IRSN/DEI/ 2011-012.

Beck, C., 2009. Late quaternary lacustrine paleo-seismic archives in north-western alps: examples of earthquake-origin assessment of sedimentary disturbances. EarthScience Reviews 96, 327-344.

Beck, C., Manalt, F., Chapron, E., Rensbergen, P.V., De Batist, M., 1996. Enhanced seismicity in the early post-glacial period: evidence from the post-würm sediments of Lake Annecy, northwestern alps. Journal of Geodynamics 22, 155-171.

Behar, F., Beaumont, V., Penteado, H.D.B., 2001. Rock-Eval 6 technology: performances and developments. Oil \& Gas Science and Technology 56, 111-134. 
Bertrand, S., Charlet, F., Chapron, E., Fagel, N., De Batist, M., 2008. Reconstruction of the Holocene seismotectonic activity of the southern Andes from seismites recorded in Lago Icalma, Chile, $39^{\circ} \mathrm{S}$. Palaeogeography, Palaeoclimatology, Palaeoecology 259 301-322.

Bertrand, S., Araneda, A., Vargas, P., Jana, P., Fagel, N., Urrutia, R., 2012. Using the N/C ratio to correct bulk radiocarbon ages from lake sediments: Insights from Chilean Patagonia. Quaternary Geochronology 12, 23-29.

Blaauw, M., 2010. Methods and code for "classical" age-modelling of radiocarbon sequences. Quaternary Geochronology 5, 512-518.

Blott, S.J., Pye, K., 2001. GRADISTAT: a grain size distribution and statistics package for the analysis of unconsolidated sediments. Earth Surface Processes and Landforms 26 1237-1248.

Boivin, P., Besson, J.-C., Briot, D., Gourgaud, A., 2009. Volcanologie de la chaîne Des Puys. Parc Naturel Régional des Volcans d'Auvergne (196 pp.).

Campos, C., Beck, C., Crouzet, C., Carrillo, E., Van Welden, A., Tripsanas, E., 2014. Late Quaternary paleoseismic sedimentary archive from deep central Gulf of Corinth: time distribution of inferred earthquake-induced layers. Annals of Geophysics (S.I.) 56,6 .

Chapron, E., Van Rensbergen, P., De Batist, M., Beck, C., Henriet, J.P., 2004. Fluid-escape features as a precursor of a large sublacustrine sediment slide in Lake Le Bourget, NW alps, France. Terra Nova 16, 305-311.

Chapron, E., Ariztegui, D., Mulsow, S., Villarosa, G., Pino, M., Outes, V., Juvignié, E., Crivelli, E., 2006. Impact of the 1960 major subduction earthquake in northern Patagonia (Chile, Argentina). Quaternary International 158, 58-71.

Chapron, E., Albéric, P., Jézéquel, D., Versteeg, W., Bourdier, J.-L., Sitbon, J., 2010. Multidisciplinary characterisation of sedimentary processes in a recent maar lake (Lake Pavin French Massif Central) and implication for natural hazards. Natural Hazards and Earth System Sciences 10, 1815-1827.

Chapron, E., Ledoux, G., Simonneau, A., Albéric, P., St-Onge, G., Lajeunesse, P., Boivin, P. Desmet, M., 2012. New evidence of Holocene mass wasting events in recent volcanic lakes from the French Massif Central (Lakes Pavin, Montcineyre and Chauvet) and implications for natural hazards. In: Yamada, Y., Kawamura, K., Ikehara, K., Ogawa, Y. Urgeles, R., Mosher, D., Chaytor, J., Strasser, M. (Eds.), Submarine Mass Movements and their Consequences. Springer, Netherlands, Dordrecht, pp. 255-264.

Chapron, E., Simonneau, A., Ledoux, G., Arnaud, F., Lajeunesse, P., Albéric, P., 2016. French alpine foreland Holocene paleoseismicity revealed by coeval mass wasting deposits. In: Lamarche, G., Mountjoy, J., Bull, S., Hubble, T., Krastel, S. Lane, E., Micallef, A., Moscardelli, L., Mueller, C., Pecher, I., Woelz, S. (Eds.), Submarine Mass Movements and their Consequences. Springer, Netherlands, Dordrecht, pp. 341-350.

Chassiot, L., 2015. Forçages Naturels et Anthropiques Sur la sédimentation holocène en Domaine Lacustre: Application Aux Lacs d'Auvergne et Aux réservoirs Des Bassins Versants de la Loire et d'Adour-Garonne (Thèse de l'Université d'Orléans. 500 pp.).

Chassiot, L., Chapron, E., Di Giovanni, C., Albéric, P., Lajeunesse, P., Lehours, A.-C., Meybeck M., 2016. Extreme events in the sedimentary record of maar Lake Pavin: implication for natural hazards assessment in the French Massif Central. Quaternary Science Reviews 141, 9-25.

Croudace, I.W., Rindby, A., Rothwell, R.G., 2006. ITRAX; description and evaluation of a new multi-function X-ray core scanner. In: Rothwell, R.G. (Ed.), New Techniques in Sediment Core Analysis. Geological Society Special Publications 267 pp. 51-63.

Debret, M., Sebag, D., Desmet, M., Balsam, W., Copard, Y., Mourier, B., Susperrigui, A.-S. Arnaud, F., Bentaleb, I., Chapron, E., Lallier-Vergès, E., Winiarski, T., 2011. Spectrocolorimetric interpretation of sedimentary dynamics: The new "07/4 diagram.". Earth-Science Reviews 109, 1-19.

Doughty, M., Eyles, N., Eyles, C.H., Wallace, K., Boyce, J.I., 2014. Lake sediments as natura seismographs: earthquake-related deformations (seismites) in central Canadian lakes. Sedimentary Geology 313, 45-67.

Folk, R.L., Ward, W.C., 1957. Brazos River bar: a study in the significance of grain size parameters. Journal of Sedimentary Petrology 27, 3-26.

Gay, I., Macaire, J.-J., 1999. Estimation des taux d'érosion chimique tardiglaciaires et holocènes par la méthode des bilans d'altération. Application au bassin du lac Chambon Massif Central, France). Comptes Rendus de l'Académie des Sciences-Series IIA-Earth and Planetary Science 328, 387-392.

Girardclos, S., Schmidt, O.T., Sturm, M., Ariztegui, D., Pugin, A., Anselmetti, F.S., 2007. The 1996 AD delta collapse and large turbidite in Lake Brienz. Marine Geology 241 137-154.

Gomez, B., Corral, A., Orpin, A.R., Page, M.J., Pouderoux, H., Upton, P., 2015. Lake Tutira paleoseismic record confirms random, moderate to major and/or great Hawke's bay (New Zealand) earthquakes. Geology 43, 103-106.

Grimm, E.C., Maher, L.J., Nelson, D.M., 2009. The magnitude of error in conventional bulksediment radiocarbon dates from central North America. Quaternary Research 72 , 301-308.

Howarth, J.D., Fitzsimons, S.J., Norris, R.J., Jacobsen, G.E., 2014. Lake sediments record high intensity shaking that provides insight into the location and rupture length of large earthquakes on the Alpine Fault, New Zealand. Earth and Planetary Science Letters 403, 340-351.

Inouchi, Y., Kinugasa, Y., Kumon, F., Nakano, S., Yasumatsu, S., Shiki, T., 1996. Turbidites as records of intense palaeoearthquakes in Lake Biwa, Japan. Sedimentary Geology Marine Sedimentary Events and Their Records 104, 117-125.

Juvigné, E., 1992. Approche de l'âge de deux cratères volcaniques lacustres d'Auvergne (France). Comptes Rendus de l'Académie des Sciences. Série 2, Mécanique, Physique, Chimie, Sciences de l'univers, Sciences de la Terre 314, 401-404.

Juvigné, É., Bastin, B., 1995. Téphrostratigraphie et palynologie de tourbes du Boréal et de l'Atlantique dans le Massif Central (France). Géographie Physique et Quaternaire 49 207-216.
Juvigné, E., Stach-Czerniak, A., 1998. Étude sédimentologique et palynologique des dépots lacustres tardiglaciaires et holocènes du Gour de Tazenat (Massif Central, France). Sedimentological and palynological investigations of late glacial and Holocene lacustrine deposits of the Gour de Tazenat (Massif Central, France). Quaternaire 9, 15-23.

Juvigné, E., Bastin, B., Delibrias, G., Evin, J., Gewelt, M., Gilot, E., Streel, M., 1996. A comprehensive pollen- and tephra-based chronostratigraphic model for the Late Glacial and Holocene period in the French Massif Central. Quaternary International 34-36, 113-120.

Karlin, R.E., Holmes, M., Abella, S.E.B., Sylwester, R., 2004. Holocene landslides and a 3500year record of Pacific northwest earthquakes from sediments in Lake Washington. Geological Society of America Bulletin 116, 94-108.

Lajeunesse, P., Sinkunas, B., Morissette, A., Normandeau, A., Joyal, G., St-Onge, G., Locat, J., 2016. Large-scale seismically-induced mass-movements in a former glacial lake basin: Lake Témiscouata, Northeastern Appalachians (Eastern Canada). Marine Geology (in press)

Lambert, J., Bernard, P., Czitrom, G., Dubié, J.-Y., Godefroy, P., Levret-Albaret, A., 1997. Les Tremblements de Terre en France, Hier, aujourd'hui, Demain.... BRGM Editions (196 pp.)

Lavrieux, M., Disnar, I.-R., Chapron, E., Bréheret, J.-G., Jacob, J., Miras, Y., Reyss, J.-L., AndrieuPonel, V., Arnaud, F., 2013. 6700 yr sedimentary record of climatic and anthropogenic signals in Lake Aydat (French Massif Central). The Holocene 23, 1317-1328.

Locat, J., Turmel, D., Habersetzer, M., Trottier, A.-P., Lajeunesse, P., St-Onge, G., 2016. Earthquake induced landslides in Lake Eternité, Québec, Canada. In: Lamarche, G., Mountjoy, J., Bull, S., Hubble, T., Krastel, S., Lane, E., Micallef, A., Moscardelli, L. Mueller, C. Pecher, I., Woelz, S. (Eds.), Submarine Mass Movements and their Consequences. Springer, Netherlands, Dordrecht, pp. 341-350.

Macaire, J.-J., Bossuet, G., Choquier, A., Cocirta, C., De Luca, P., Dupis, A., Gay, I., Mathey, E., Guenet, P., 1997. Sediment yield during late glacial and Holocene periods in the Lac Chambon watershed, Massif Central, France. Earth Surface Processes and Landforms 22, 473-489.

Maloney, J.M., Noble, P.J., Driscoll, N.W., Kent, G.M., Smith, S.B., Schmauder, G.C., Babcock, J.M., Baskin, R.L., Karlin, R, Kell, A.M., Seitz, G.G, Zimmerman, S., Kleppe, J A, 2013. Paleoseismic history of the fallen leaf segment of the West Tahoe-Dollar point fault reconstructed from slide deposits in the Lake Tahoe Basin, California-Nevada. Geosphere 9, 1065-1090.

Merle, O., Michon, L., Camus, G., de Goer, A., 1998. L'extension oligocène sur la transversale septentrionale du rift du Massif Central. Bulletin de la Société Géologique de France 169, 615-626.

Moernaut, J., De Batist, M., Charlet, F., Heirman, K., Chapron, E., Pino, M., Brümmer, R., Urrutia, R., 2007. Giant earthquakes in south-Central Chile revealed by Holocene mass-wasting events in Lake Puyehue. Sedimentary Geology 195, 239-256.

Moernaut, J., Daele, M.V., Heirman, K., Fontijn, K., Strasser, M., Pino, M., Urrutia, R., De Batist, M., 2014. Lacustrine turbidites as a tool for quantitative earthquake reconstruction: new evidence for a variable rupture mode in south Central Chile. Journal of Geophysical Research: Solid Earth 119, 1607-1633.

Monecke, K., Anselmetti, F.S., Becker, A., Sturm, M., Giardini, D., 2004. The record of historic earthquakes in lake sediments of Central Switzerland. Tectonophysics 394, 21-40.

Morey, A.E Goldfinger, C., Briles, C.E., Gavin, D.G., Colombaroli, D., Kusler, J.E., 2013. Are great Cascadia earthquakes recorded in the sedimentary records from small forearc lakes? Natural Hazards and Earth System Sciences 13, 2441-2463.

Mulder, T., Cochonat, P., 1996. Classification of offshore mass movements. Journal of Sedimentary Research 66, 43-57.

Nomade, J., Chapron, E., Desmet, M., Reyss, J.-L., Arnaud, F., Lignier, V., 2005. Reconstructing historical seismicity from lake sediments (Lake Laffrey, Western Alps, France). Terra Nova 17, 350-357.

Nomade, S., Scaillet, S., Pastre, J.-F., Nehlig, P., 2012. Pyroclastic chronology of the Sancy stratovolcano (Mont-Dore, French Massif Central): new high-precision $40 \mathrm{Ar} / 39 \mathrm{Ar}$ constraints. Journal of Volcanology and Geothermal Research 225226, $1-12$.

Nomade, S., Pastre, J.-F., Nehlig, P., Guillou, H., Scao, V., Scaillet, S., 2014. Tephrochronology of the Mont-Dore volcanic massif (Massif Central, France): new 40Ar/39Ar constraints on the Late Pliocene and Early Pleistocene activity. Bulletin of Volcanology $76,798$.

Pouderoux, H., Proust, J.-N., Lamarche, G., 2014. Submarine paleoseismology of the Northern Hikurangi subduction margin of New Zealand as deduced from turbidite record since $16 \mathrm{ka}$. Quaternary Science Reviews 84, 116-131.

Reimer, P.J., Bard, E., Bayliss, A., Beck, J.W., Blackwell, P.G., Bronk Ramsey, C., Buck, C.E., Cheng, H., Edwards, R.L., Friedrich, M., Grootes, P.M., Guilderson, T.P., Haflidason, H., Hajdas, I., Hatté, C., Heaton, T.J., Hoffmann, D.L., Hogg, A.G., Hughen, K.A., Felix Raiser, K., Kromer, B., Manning, S.W., Niu, M., Reimer, R.W., Richards, D.A., Marian Scott, E., Southon, J.R., Staff, R.A., Turney, C.S.M., van der Plicht, J., 2013. IntCal13 and Marine13 radiocarbon age calibration curves 0-50,000 years cal BP. Radiocarbon $55,1869-1887$.

Rioual, P., 2002. Limnological characteristics of 25 lakes of the French Massif Central. Annales de Limnologie 38, 311-327.

Schettler, G., Schwab, M.J., Stebich, M., 2007. A 700-year record of climate change based on geochemical and palynological data from varved sediments (lac Pavin, France). Chemical Geology 240, 11-35.

Schnellmann, M., Anselmetti, F.S., Giardini, D., McKenzie, J.A., Ward, S.N., 2002. Prehistoric earthquake history revealed by lacustrine slump deposits. Geology 30, 1131

Schwab, M.J., Werner, P., Dulski, P., McGee, E., Nowaczyk, N.R., Bertrand, S., Leroy, S.A.G., 2009. Palaeolimnology of Lake Sapanca and identification of historic earthquake signals, Northern Anatolian Fault Zone (Turkey). Quaternary Science Reviews 28, 991-1005. 
Simonneau, A., Chapron, E., Vannière, B., Wirth, S.B., Gilli, A., Di Giovanni, C., Anselmetti, F.S., Desmet, M., Magny, M., 2013. Mass-movement and flood-induced deposits in Lake Ledro, southern Alps, Italy: implications for Holocene palaeohydrology and natural hazards. Climate of the Past 9, 825-840.

Smith, S.B., Karlin, R.E., Kent, G.M., Seitz, G.G., Driscoll, N.W., 2013. Holocene subaqueous paleoseismology of Lake Tahoe. Geological Society of America Bulletin 125, 691-708.

Stebich, M., Brüchmann, C., Kulbe, T., Negendank, J.F.W., 2005. Vegetation history, human impact and climate change during the last 700 years recorded in annually laminated sediments of Lac Pavin, France. Review of Palaeobotany and Palynology 133, 115-133.

St-Onge, G., Mulder, T., Piper, D.J.W., Hillaire-Marcel, C., Stoner, J.S., 2004. Earthquake and flood-induced turbidites in the Saguenay Fjord (Québec): a Holocene paleoseismicity record. Quaternary Science Reviews 23, 283-294.

Strasser, M., Anselmetti, F.S., Fäh, D., Giardini, D., Schnellmann, M., 2006. Magnitudes and source areas of large prehistoric northern alpine earthquakes revealed by slope failures in lakes. Geology 34, 1005-1008.

Strasser, M., Monecke, K., Schnellmann, M., Anselmetti, F.S., 2013. Lake sediments as natural seismographs: a compiled record of Late Quaternary earthquakes in Central Switzerland and its implication for alpine deformation. Sedimentology 60, 319-341.
Stucchi, M., Rovida, A., Gomez Capera, A.A., Alexandre, P., Camelbeeck, T., Demircioglu, M.B., Gasperini, P., Kouskouna, V., Musson, R.M.W., Radulian, M., Sesetyan, K., Vilanova, S., Baumont, D., Bungum, H., Fäh, D., Lenhardt, W., Makropoulos, K. Martinez Solares, J.M., Scotti, O., Živčić, M., Albini, P., Batllo, J., Papaioannou, C. Tatevossian, R., Locati, M., Meletti, C., Viganò, D., Giardini, D., 2013. The SHARE European earthquake catalogue (SHEEC) 1000-1899. Journal of Seismology 17, $523-544$.

Terrier, M., Bles, J.L., Godefroy, P., Dominique, P., Bour, M., Martin, C., 2000. Zonation of metropolitan France for the application of earthquake-resistant building regulations to critical facilities part 1: seismotectonic zonation. Journal of Seismology 4, 215-230.

Vidal, N., de Goër de Hervé, A., Camus, G., 1996. Déstabilisation de reliefs, d'érosion en terrain volcanique. Exemples pris dans le Massif Central français. Collapse of erosional relief in volcanic terrains. Examples from the Massif Central, France. Quaternaire 7 117-127.

Wilhelm, B., Nomade, J., Crouzet, C., Litty, C., Sabatier, P., Belle, S., Rolland, Y., Revel, M., Courboulex, F., Arnaud, F., Anselmetti, F.S., 2015. Quantified sensitivity of small lake sediments to record historic earthquakes: implications for paleoseismology. Journal of Geophysical Research: Earth Surface 121, 2-16. 